\title{
Environmental influences on carbon dioxide fluxes over three grassland ecosystems in China
}

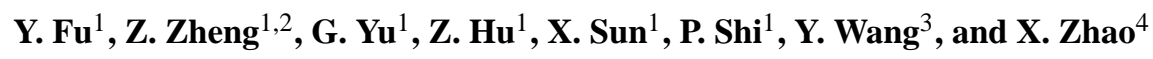 \\ ${ }^{1}$ Key Laboratory of Ecosystem Network Observation and Modeling, Institute of Geographic Sciences and Natural Resources \\ Research, Chinese Academy of Sciences, Beijing 100101, China \\ ${ }^{2}$ East China Normal University, Shanghai 200062, China \\ ${ }^{3}$ The Graduate University of Chinese Academy of Sciences, Beijing 100039, China \\ ${ }^{4}$ Northwest Plateau Institute of Biology, Chinese Academy of Sciences, Xining 810001, China
}

Received: 1 June 2009 - Published in Biogeosciences Discuss.: 6 August 2009

Revised: 29 November 2009 - Accepted: 30 November 2009 - Published: 7 December 2009

\begin{abstract}
This study compared carbon dioxide $\left(\mathrm{CO}_{2}\right)$ fluxes over three grassland ecosystems in China, including a temperate semiarid steppe in Inner Mongolia (NMG), an alpine shrub-meadow in Qinghai (HB), and an alpine meadowsteppe in Tibet (DX). Measurements were made in 2004 and 2005 using the eddy covariance technique. Objectives were to document the seasonality of the net ecosystem exchange of $\mathrm{CO}_{2}$ (NEE) and its components, gross ecosystem photosynthesis (GEP), and ecosystem respiration $\left(R_{\mathrm{eco}}\right)$, and to examine how environmental factors affect the $\mathrm{CO}_{2}$ exchange in these grassland ecosystems. The 2005 growing season (from May to September) was warmer than that of 2004 across the three sites, and precipitation in 2005 was less than that in 2004 at NMG and DX. The magnitude of $\mathrm{CO}_{2}$ fluxes (daily and annual sums) was largest at $\mathrm{HB}$, which also showed the highest temperature sensitivity of $R_{\text {eco }}$ among the three sites. A stepwise multiple regression analysis showed that the seasonal variation of GEP, $R_{\text {eco }}$, and NEE of the alpine shrubmeadow was mainly controlled by air temperature, whereas leaf area index can likely explain the seasonal variation in GEP, $R_{\text {eco }}$, and NEE of the temperate steppe. The $\mathrm{CO}_{2}$ fluxes of the alpine meadow-steppe were jointly affected by soil moisture and air temperature. The alpine shrub-meadow acted as a net carbon sink over the two study years, whereas the temperate steppe and alpine meadow-steppe acted as net carbon sources. Both GEP and $R_{\text {eco }}$ were reduced by the summer and spring drought in 2005 at NMG and DX, respectively. The accumulated leaf area index during the grow-
\end{abstract}

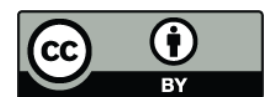

Correspondence to: $\mathrm{G}$. $\mathrm{Yu}$ (yugr@igsnrr.ac.cn) ing season $\left(\mathrm{LAI}_{\text {sum }}\right)$ played a key role in the interannual and intersite variation of annual GEP and $R_{\text {eco }}$ across the study sites and years, whereas soil moisture contributed most significantly to the variation in annual NEE. Because LAI $_{\text {sum }}$ was significantly correlated with soil moisture at a depth of $20 \mathrm{~cm}$, we concluded that the available soil moisture other than annual precipitation was the most important factor controlling the variation in the $\mathrm{CO}_{2}$ budgets of different grassland ecosystems in China.

\section{Introduction}

In recent years, the carbon cycle in terrestrial ecosystems has attracted considerable attention not only among scientists but also among policymakers, owing to its potential for sequestering atmospheric $\mathrm{CO}_{2}$ (IPCC, 2001). Many studies have focused on the $\mathrm{CO}_{2}$ exchange in forests ecosystems because of the forests' potential to sequester large amounts of carbon (Pacala et al., 2001). Less attention had been paid to the $\mathrm{CO}_{2}$ exchange in grasslands, even though these lands comprise approximately $32 \%$ of the earth's natural vegetation (Syuker et al., 2003). There are evidences that some grasslands can be significant sources or sinks of atmospheric $\mathrm{CO}_{2}$ (Harazono et al., 2003; Novick et al., 2004; Gilmanov et al., 2007), while other of these lands are carbon neutral (Suyker et al., 2003). However, most grassland ecosystems show large interannual variability in the annual net ecosystem exchange of $\mathrm{CO}_{2}$ (NEE) and may even achieve negative annual $\mathrm{CO}_{2}$ uptake (Flanagan et al., 2002; Ma et al., 2007).

There is clearly a great deal of uncertainty regarding the role of grasslands in the global carbon budget, and the drivers

Published by Copernicus Publications on behalf of the European Geosciences Union. 
of $\mathrm{CO}_{2}$ flux dynamics differ among a range of grasslands under various climatic conditions and management practices (Knapp et al., 2002; Verburg et al., 2004; Derner et al., 2006). Studies have shown that the annual amount and the timing of precipitation remain dominant factors in the $\mathrm{CO}_{2}$ exchange in temperate semiarid grassland and Mediterranean grassland (Suyker et al., 2003; Hunt et al., 2004; Xu and Baldocchi, 2004). In addition, temperate grasslands show asymmetric responses to interannual variations in precipitation. Indeed, the productivity increases during wet years are much more pronounced than the reductions in productivity occurring during dry years (Wever et al., 2002; Flanagan et al., 2002).

There are large areas of temperate and alpine grasslands on Inner Mongolia Plateau and Qinghai-Tibet Plateau, respectively, in China. The temperate steppe represents one of the typical vegetation types on the Eurasian continent, and half of its total area (about 84 million ha) is located in China (Li et al., 1998). This ecosystem is more xeric and water stressed than many other ecosystems and is ecologically fragile and sensitive to climate change ( $\mathrm{Li}$ et al., 2005; Niu et al., 2008). Research has documented a gradually warmer and drier climate in this area (McCarthy et al., 2001; Chen et al., 2003). An experimental study has found reductions in $\mathrm{CO}_{2}$ flux under warming, whereas increased precipitation stimulated ecosystem $\mathrm{CO}_{2}$ fluxes and also alleviated the negative effects of warming on NEE (Niu et al., 2008). Meanwhile, the alpine meadow ecosystems on the Qinghai-Tibet Plateau, covering an area of approximately $2.5 \times 10^{6} \mathrm{~km}^{2}$ (Zhao et al., 2006) and with higher soil carbon density than those savannas and temperate grasslands (Adams et al., 1990; Ni, 2002), may have played an important role in global carbon cycles. Studies have indicated that alpine meadows are highly sensitive to temperature change (Harazono et al., 2003; Kato et al., 2006) and may have significant potential for releasing $\mathrm{CO}_{2}$ under climatic warming because of the sensitivity of frigid soil to warming (Wang et al., 2002).

Several studies have addressed $\mathrm{CO}_{2}$ fluxes over the grasslands in China (e.g. Kato et al., 2004; Zhao et al., 2005; Shi et al., 2006; Hao et al., 2007; Wang et al., 2008), but none synthetically studied the $\mathrm{CO}_{2}$ exchange and its relationship with environmental factors across different grassland types or biomes. In this study we presented measurements of $\mathrm{CO}_{2}$ flux over three grassland ecosystems in China in 2004 and 2005. Our objectives were to (1) quantify the seasonal and interannual variation in NEE and its major components, gross ecosystems production (GEP), and ecosystem respiration $\left(R_{\mathrm{eco}}\right)$ and $(2)$ to clarify the major environmental factors affecting the intra- and inter-site variation in $\mathrm{CO}_{2}$ fluxes among three grassland ecosystems in China. We hypothesized that (1) precipitation dominates the $\mathrm{CO}_{2}$ fluxes in the temperate steppe and temperature constrains $\mathrm{CO}_{2}$ exchange in alpine meadows; (2) at regional scale, precipitation dominates the spatial variation in the grassland $\mathrm{CO}_{2}$ budget.

\section{Materials and methods}

\subsection{Site description}

Measurements were conducted in 2004 and 2005 over three grassland ecosystems located on the Inner Mongolia Plateau and Qinghai-Tibet Plateau in China, including a temperate Leymus chinensis steppe, an alpine Potentilla fruticosa shrub-meadow, and an alpine Kobresia pygmaea meadowsteppe. These communities represent China's most prevalent grassland types (Fan et al., 2008).

The temperate Leymus chinensis steppe is located in the Xilin River Basin in Inner Mongolia (NMG). There are low hills in the study area, with relative height difference of 20$30 \mathrm{~m}$ and a terrain slope of less than $3 \%$. The area has a substantial amount of accumulated surface litter as a result of 20 years non-grazing. The alpine Potentilla fruticosa shrubmeadow is located in Haibei Tibetan Autonomous Prefecture (HB) in Qinghai Province in northeast of the Qinghai-Tibet Plateau. The study area one kilometer around the flux tower is fairly flat, with a slope of less than $1 \%$. The alpine Kobresia pygmaea meadow-steppe is located in Damxung County (DX), in the south of the Qinghai-Tibet Plateau. The terrain of this study area is fairly open and flat, with a slope of less than $2 \%$. Table 1 provides extensive descriptions of the three sites. For further details about the study sites, refer to our previous papers (Fu et al., 2006b; Hao et al., 2007; Zhao et al, 2006; Shi et al., 2006).

\subsection{Field measurements}

Eddy covariance $\mathrm{CO}_{2}$ flux was measured with the same instruments at a height of $2.5 \mathrm{~m}$ at the three sites. The eddy covariance system included a three-dimensional sonic anemometer (Model CSAT-3, Campbell Scientific, Logan, Utah, USA) and an open-path infrared $\mathrm{CO}_{2} / \mathrm{H}_{2} \mathrm{O}$ analyzer (Model LI-7500, Li-Cor Inc., Nebraska, USA). The flux data were recorded by a datalogger (CR5000, Campbell Scientific) at 30 min intervals.

The meteorological variables were measured simultaneously with eddy fluxes. Solar radiation and net radiation was measured at a height of $1.5 \mathrm{~m}$ above the ground with a fourcomponent net radiometer (Model CNR-1, Kipp \& Zonen, The Netherlands). Photosynthetically active radiation (PAR) was measured with a quantum sensor (LI190SB, Li-cor Inc.). Air temperature $\left(T_{a}\right)$ and relative humidity $(\mathrm{RH})$ were measured at 1.5 and $2.5 \mathrm{~m}$ heights using shielded and aspirated probes (Model HMP45C, Campbell Scientific). Precipitation $(P)$ was measured with a rain gauge (Model 52203, RM Young Inc., Traverse City, Michigan, USA). Soil temperature $\left(T_{s}\right)$ was measured at five depths (Table 1) with thermometers (Model 107-L, Campbell Scientific). We monitored soil moisture $\left(S_{w}\right)$ with time-domain reflectometry (TDR, Model CS615-L, Campbell Scientific) at three depths at NMG and DX and two depths at HB (Table 1). All meteorological data 
Table 1. Sites description.

\begin{tabular}{|c|c|c|c|}
\hline Site name (ab.) & Inner Mongolia (NMG) & Haibei (HB) & Damxung (DX) \\
\hline Location & $43^{\circ} 32^{\prime} \mathrm{N}, 116^{\circ} 40^{\prime} \mathrm{E}$ & $37^{\circ} 39^{\prime}, 55^{\prime \prime} \mathrm{N}, 101^{\circ} 19^{\prime} 52^{\prime \prime} \mathrm{E}$ & $30^{\circ} 51^{\prime} \mathrm{N}, 91^{\circ} 05^{\prime} \mathrm{E}$ \\
\hline Elevation (m) & 1189 & 3293 & 4333 \\
\hline $\begin{array}{l}\text { Mean annual tem- } \\
\text { perature }\left({ }^{\circ} \mathrm{C}\right)\end{array}$ & $-1.1-1$ & -1.7 & 1.3 \\
\hline $\begin{array}{l}\text { Annual precipita- } \\
\text { tion }(\mathrm{mm})\end{array}$ & 350 & 570 & 480 \\
\hline Ecosystem type & temperate steppe & alpine shrub-meadow & alpine meadow- steppe \\
\hline Dominant species & $\begin{array}{l}\text { Leymus chinensis, } \\
\text { Stipa grandis, } \\
\text { Koeleria cristata, } \\
\text { Agropyron cristatum }\end{array}$ & $\begin{array}{l}\text { Potentilla fruticisa L., } \\
\text { Stipa aliena, } \\
\text { Kobresia capillifolia, } \\
\text { Kobresia humilis }\end{array}$ & $\begin{array}{l}\text { Stipa capillacea, } \\
\text { Carex montis-everestii, Kobre- } \\
\text { sia pygmaea }\end{array}$ \\
\hline Canopy height $(\mathrm{cm})$ & $50-60$ & $55-70$ & $<10$ \\
\hline $\begin{array}{l}\text { Vegetation cover- } \\
\text { age }\end{array}$ & $30 \%-70 \%$ & $>80 \%$ & $<50 \%$ \\
\hline Soil type & $\begin{array}{l}\text { dark chestnut (Mollic Gryic } \\
\text { Cambisols) }\end{array}$ & $\begin{array}{l}\text { silty clay loam (Mol-Cryic } \\
\text { Cambisols) }\end{array}$ & sandy loam of meadow soil \\
\hline Management & Fenced since 1979 & Grazed in winter & Grazed in winter \\
\hline $\begin{array}{l}\text { Depth of soil tem- } \\
\text { perature }(\mathrm{m})^{*}\end{array}$ & $0.05,0.1,0.2,0.5,1.0$ & $0.05,0.1,0.2,0.5,1.0$ & $0.05,0.1,0.2,0.5,1.0$ \\
\hline $\begin{array}{l}\text { Depth of soil mois- } \\
\text { ture }(\mathrm{m})^{\mathrm{a}}\end{array}$ & $0.05,02,0.5$ & $0.2,0.4$ & $0.05,0.2,0.5$ \\
\hline
\end{tabular}

* The height and depth indicate the location of the sensors mounted.

were recorded at half-hour intervals. More details about the monitoring system are available in previously published paper (Fu et al., 2006b).

\subsection{Eddy covariance flux data processing}

Prior to conducting the scalar flux computation, we applied three-dimensional rotation to align the coordinate system with the mean wind (Wilczak et al., 2001). The WPL method was applied to adjust density changes resulting from fluctuations in heat and water vapor (Webb et al., 1980). We screened the eddy covariance $\mathrm{CO}_{2}$ flux data for anomalous or spurious values outside the range normally encountered. Possible causes for such values can include sensor malfunction and interference from rain, dew, hoarfrost, birds, etc. The eddy covariance technique has been found to underestimate nighttime $\mathrm{CO}_{2}$ fluxes (ecosystem respiration, $R_{\text {eco }}$ ) under low-atmospheric turbulence conditions (Wohlfahrt et al., 2005). Here, we followed the current practice of screening the nighttime data by using site-specific thresholds of friction velocity $\left(u_{*}\right)$ (Aubinet et al., 2000). The threshold of $u_{*}$ was determined by plotting nighttime $\mathrm{CO}_{2}$ fluxes to friction velocity at each site, and above which the $\mathrm{CO}_{2}$ fluxes seem to level off (Massman and Lee, 2002). It was identified as $0.2 \mathrm{~m} \mathrm{~s}^{-1}$ for NMG and $0.15 \mathrm{~m} \mathrm{~s}^{-1}$ for HB and DX, respectively. Negative $\mathrm{CO}_{2}$ fluxes at nighttime (i.e., apparent "photosynthesis") were also removed from the datasets. Data gaps were thus produced. The average daytime and nighttime data coverage was $71 \%$ and $21 \%$ for $\mathrm{NMG}, 73 \%$ and $23 \%$ for $\mathrm{HB}$, $78 \%$ and $22 \%$ at DX, respectively. The overall data coverage during the two years was $46 \%, 48 \%$ and $50 \%$ for $\mathrm{NMG}, \mathrm{HB}$ and DX, respectively.

To obtain the information on annual sums of the $\mathrm{CO}_{2}$ flux, the data gaps were filled with the nonlinear regressions method suggested by Falge et al. (2001) and Reichstein et al. (2005). For small gaps $(<2 \mathrm{~h})$, the missing data were linearly interpolated. For larger gaps $(2 \mathrm{~h}$ to several consecutive days), the missing daytime $\mathrm{CO}_{2}$ flux (net ecosystem exchange of $\mathrm{CO}_{2}$, NEE) during the growing season was estimated as a function of PAR using the Michaelis-Menten equation with a 10-days moving window (Falge et al., 2001, their Eq. A8):

$\mathrm{NEE}=\frac{\alpha \cdot \mathrm{PAR} \cdot P_{\max }}{\alpha \cdot \mathrm{PAR}+P_{\max }}-R_{\text {eco,day }}$

where $\alpha$ is ecosystem apparent quantum yield $\left(\mathrm{mg} \mathrm{CO}_{2} \mu\right.$ mol quantum $\left.{ }^{-1}\right), P_{\max }$ is the asymptotic GEP at saturating light, and $R_{\text {eco,day }}$ is the average daytime ecosystem respiration (both $\mathrm{mg} \mathrm{CO}_{2} \mathrm{~m}^{-2} \mathrm{~s}^{-1}$ ). $\alpha, P_{\max }$ and $R_{\text {eco,day }}$ are fitted parameters with the observed valid data using the nonlinear regression of MATLAB 7.0.

The missing daytime $\mathrm{CO}_{2}$ flux during dormant season and the missing nighttime $\mathrm{CO}_{2}$ flux (indicated as ecosystem respiration, $R_{\text {eco }}$ ) were estimated with the empirical relationships between $R_{\text {eco }}$ and soil temperature and soil moisture. The missing $R_{\text {eco }}$ at HB and DX was estimated using Lloyd 
and Taylor equation (Lloyd and Taylor, 1994, their Eq. 11) with the available measured data within the entire year:

$R_{\mathrm{eco}}=R_{\mathrm{eco}, T_{\mathrm{ref}}} e^{E_{0}\left[1 /\left(T_{\mathrm{ref}}-T_{0}\right)-1 /\left(T_{s}-T_{0}\right)\right]}$

where $R_{\text {eco, }, T_{\text {ref }}}$ is ecosystem respiration rate $\left(\mathrm{mg} \mathrm{CO}_{2} \mathrm{~m}^{-2}\right.$ $\mathrm{s}^{-1}$ ) at reference temperature ( $T_{\text {ref }}$, set as $273.16 \mathrm{~K}$ in this study). $E_{0}$ is the parameter that essentially determines the temperature sensitivity of ecosystem respiration (set as $309 \mathrm{~K}$ in this study, Falge et al., 2001). $T_{s}$ is measured soil temperature at $5 \mathrm{~cm}$ depth $(\mathrm{K})$.

Previous studies showed that soil moisture could have potential effects on $R_{\text {eco }}$ and its temperature sensitivity for the ecosystems frequently experiencing drought, e.g., NMG in this study (Fu et al., 2006a). Therefore, both soil temperature and soil moisture were taken into account in the estimation of missing $R_{\text {eco }}$ data during non-frozen period (from April to October) at NMG:

$$
\begin{aligned}
& R_{\mathrm{eco}}=R_{\mathrm{eco}, T_{\mathrm{ref}}} e^{\ln \left(Q_{10}\right)\left(T_{s}-T_{\mathrm{ref}}\right) / 10} \\
& Q_{10}=a-b T_{s}+c S_{w}+d S_{w}^{2}
\end{aligned}
$$

where $Q_{10}$ is the temperature sensitivity of ecosystem respiration, $T_{s}$ is the measured soil temperature at $5 \mathrm{~cm}$ depth (K). $S_{w}$ is soil volumetric moisture content $\left(\mathrm{m}^{3} \mathrm{~m}^{-3}\right)$ at $5 \mathrm{~cm}$ depth at NMG site. $a, b, c$ and $d$ are site-specific parameters fitted with the valid data during the non-frozen season, in which $b>0$ and $d \leq 0$. The missing $R_{\text {eco }}$ data at NMG during the frozen period (from January to March and from November to December) were also estimated with the Lloyd and Taylor equation (Eq. 2).

These estimates of $R_{\text {eco }}$ were also used to calculate daytime respiration $\left(R_{\text {eco,day }}\right)$ at each site. Using the daytime respiration values, gross ecosystem production (GEP) could then be derived by subtracting the estimated daytime respiration $\left(R_{\text {eco,day }}\right)$ from the corresponding daytime NEE. Positive values represent $\mathrm{CO}_{2}$ release from the ecosystem to the atmosphere, whereas negative values signify ecosystem $\mathrm{CO}_{2}$ uptake from the atmosphere. The above computations were done with MATLAB software (Math Works Inc., Natick, MA).

\subsection{Vegetation measurements}

Leaf area index (LAI) was measured at two-week intervals (at HB and DX) or a longer period (once per month at NMG) during the growing seasons in 2004 and 2005. The sampling plot measured $50 \mathrm{~cm} \times 50 \mathrm{~cm}$, and five replicates were taken on each measurement day. LAI was measured on a sub-sample of leaves and related to dry mass (e.g. via specific leaf area, SLA, $\mathrm{cm}^{2} \mathrm{~g}^{-1}$ ). The total dry mass of leaves collected within the $50 \mathrm{~cm} \times 50 \mathrm{~cm}$ sampling plot was then converted into LAI by multiplying by the SLA. Such LAI data were only available on the measurement days, which varied among the three sites. To obtain integrated LAI dataset with relatively fine time resolution, the MODIS
NDVI products (eight days averaged with $1 \mathrm{~km}$ resolution, http://remotesensing.unh.edu) were used for the estimation of consecutive LAI datasets. We fitted the relationships between NDVI and measured LAI for each site with exponential functions $\left(R^{2}>0.94, P<0.05\right)$ and then used these functions and NDVI data to estimate the integrated LAI for the entire growing season at the three sites (Hu et al., 2008).

\subsection{Statistic analysis}

We performed a stepwise multiple regression analysis to investigate the relationships of GEP, $R_{\text {eco }}$, or NEE with concurrent changes in environmental variables $\left(T_{a}, S_{w}\right.$, PAR, $P$ ) and LAI using the monthly and annual data in SPSS (Version 11.5, SPSS Inc., IL, USA). The statistical information for the relationships between monthly GEP, $R_{\mathrm{eco}}$, or NEE and $T_{a}, S_{w}$, PAR, $P$ or LAI are listed in Table 2. In the multiple regression analysis at annual scale, we included not only the single variables $\left(T_{a}, S_{w}\right.$, PAR, $P$, and LAI) but also the interaction terms among them to study the joint effect of two or three variables on ecosystem $\mathrm{CO}_{2}$ fluxes. The multiple regression models between annual $\mathrm{CO}_{2}$ budgets (GEP, $R_{\text {eco }}$, or NEE) and the primary controlling factors across the three sites are listed in Table 3.

\section{Results}

\subsection{Comparison of environmental conditions}

Variation in environmental conditions at the three sites during 2004-2005 are plotted in Fig. 1, including monthly values of air temperature $\left(T_{a}\right)$, photosynthetically active radiation (PAR), and vapor pressure deficit (VPD). Annual trends in volumetric soil moisture and daily precipitation at the three sites are also presented in Fig. 2. Influenced by continental climate to varying degrees, the three grassland ecosystems showed distinct seasonal and interannual variations in the environmental variables. The PAR during the growing season at $\mathrm{HB}$ was generally lower than that at NMG and DX because of cloudier conditions during its summer rainy season (Fig. 1, Table 4). $T_{a}$ during the growth season at NMG was generally higher than that at HB and DX (Fig. 1b). The mean annual $T_{a}$ in 2005 was higher than that in 2004 at HB and DX. At all three sites, the growing seasons were warmer in 2005 than in 2004 (Table 4).

The amount and timing of precipitation received also represented a significant environmental difference among the three sites (Fig. 2). The annual precipitation at NMG in 2004 was near the average (Table 4), with a dry spring due to little rainfall from April through mid-June. However, it was much drier in 2005 at NMG, with significantly belowaverage precipitation, which led to a continuous decrease in soil water content from May through the entire growing season (Fig. 2a). The precipitation at HB in the two study years 
Table 2. Statistical information (regression coefficient (Coef.), partial correlation coefficient (partial $R^{2}$ ) and significance probability $(P)$ ) for the relationships between ecosystem carbon fluxes (GEP, $R_{\mathrm{eco}}$, and NEE) and air temperature $\left(T_{a}\right)$, soil moisture $\left(S_{w}\right)$, PAR, precipitation $(P)$ and leaf area index (LAI) using a stepwise multiple linear regression analysis for NMG, HB, and DX. The monthly data from May to September in 2004 and 2005 were used.

\begin{tabular}{|c|c|c|c|c|c|c|c|c|c|c|}
\hline Site & Factor $^{\mathrm{a}}$ & Coef. & $\begin{array}{r}\text { GEP } \\
\text { Partial } \\
R^{2}\end{array}$ & $P$ & Coef. & $\begin{array}{c}R_{\text {eco }} \\
\text { Partial } \\
R^{2}\end{array}$ & $P$ & Coef. & $\begin{array}{c}\text { NEE } \\
\text { Partial } \\
R^{2}\end{array}$ & $P$ \\
\hline \multirow{6}{*}{ NMG } & CONS & 12.95 & & 0.12 & 6.35 & & 0.48 & 35.11 & & $<0.001^{* * *}$ \\
\hline & $T_{a}$ & 0.025 & 0.0035 & 0.88 & 0.043 & 0.0076 & 0.82 & 0.27 & 0.28 & 0.14 \\
\hline & $S_{w}$ & -0.068 & 0.029 & 0.66 & 0.26 & 0.31 & 0.12 & 0.32 & 0.40 & 0.067 \\
\hline & PAR & -0.076 & 0.014 & 0.76 & 0.18 & 0.051 & 0.55 & -0.091 & 0.014 & 0.77 \\
\hline & $P$ & -0.082 & 0.012 & 0.78 & 0.47 & 0.29 & 0.14 & 0.23 & 0.060 & 0.53 \\
\hline & $\mathrm{LAI}^{\mathrm{b}}$ & -0.92 & 0.84 & $<0.001^{* * *}$ & 0.89 & 0.79 & $0.001^{* * *}$ & -0.88 & 0.77 & $0.001^{* * *}$ \\
\hline \multirow{6}{*}{$\mathrm{HB}$} & CONS & 41.99 & & $0.01^{* *}$ & 6.08 & & 0.43 & 47.07 & & $0.008^{* *}$ \\
\hline & $T_{a}^{\mathrm{b}}$ & -0.98 & 0.95 & $<0.001^{* * *}$ & 0.96 & 0.93 & $<0.001^{* * *}$ & -11.5 & 0.82 & $<0.001^{* * *}$ \\
\hline & $S_{w}$ & 0.014 & 0.0041 & 0.87 & -0.14 & 0.29 & 0.14 & -0.091 & 0.046 & 0.58 \\
\hline & PAR & 0.052 & 0.058 & 0.54 & 0.18 & 0.44 & $0.05^{*}$ & 0.25 & 0.33 & 0.11 \\
\hline & $P$ & -0.127 & 0.20 & 0.21 & 0.14 & 0.16 & 0.28 & -0.11 & 0.042 & 0.60 \\
\hline & $L A I$ & -0.191 & 0.23 & 0.19 & 0.28 & 0.31 & 0.12 & -0.10 & 0.017 & 0.74 \\
\hline \multirow{6}{*}{ DX } & CONS & 33.66 & & $0.009^{* *}$ & 26.92 & & $<0.001^{* * *}$ & 51.71 & & $<0.001^{* * *}$ \\
\hline & $T_{a}^{\mathrm{b}}$ & -0.44 & 0.65 & $0.009^{* *}$ & 0.35 & 0.11 & 0.39 & -0.36 & 0.53 & $0.026^{*}$ \\
\hline & $S_{w}^{\mathrm{b}}$ & -0.68 & 0.82 & $0.001^{* * *}$ & 0.13 & 0.015 & 0.76 & -0.74 & 0.83 & $0.001^{* * *}$ \\
\hline & PAR & 0.25 & 0.34 & 0.13 & 0.39 & 0.10 & 0.40 & 0.38 & 0.70 & $0.009^{* *}$ \\
\hline & $P$ & 0.13 & 0.095 & 0.46 & 0.12 & 0.02 & 0.71 & -0.001 & 0.0035 & 0.89 \\
\hline & $L A I$ & -0.22 & 0.18 & 0.24 & 0.61 & 0.38 & 0.059 & -0.1 & 0.12 & 0.40 \\
\hline
\end{tabular}

Significance of the regressions $(P)$ are $\left({ }^{*}\right),\left({ }^{* *}\right)$, or $\left(^{* * *}\right)$ for $P<0.05,0.01$, and 0.001 , respectively.

a The primary controlling factor for each site analyzed by stepwise multiple linear regression.

${ }^{\mathrm{b}}$ The interaction terms among the $T_{a}, \mathrm{PAR}, S_{w}, P$ and LAI were not included here.

Table 3. The multiple regression models and statistical information for the relationships between annual $\mathrm{CO}_{2}$ budgets $\left(\mathrm{GEP}, R_{\mathrm{eco}}\right.$, or $\left.\mathrm{NEE}\right)$ and the primary controlling factors across the three sites. $T_{a}, \mathrm{AP}, S_{w}$ and $\mathrm{LAI}_{\text {sum }}$ here indicate mean annual air temperature, annual total precipitation, average soil moisture and accumulated LAI during growing season (May to September).

\begin{tabular}{|c|c|c|c|c|c|}
\hline $\begin{array}{l}\mathrm{CO}_{2} \\
\text { fluxes }\end{array}$ & Multiple regression model & Factor & S.E. & $R^{2}$ & $P$ \\
\hline \multirow[t]{2}{*}{ GEP } & $=52.52-2.70 \mathrm{LAI}_{\text {sum }}{ }^{\mathrm{a}}$ & $\mathrm{LAI}_{\text {sum }}$ & 62.68 & 0.92 & $* * *$ \\
\hline & $=-15.96-0.005\left(\mathrm{LAI}_{\text {sum }} \times \mathrm{AP}\right)^{\mathrm{b}}$ & $\mathrm{LAI}_{\text {sum }}, \mathrm{AP}$ & 32.45 & 0.98 & $* * *$ \\
\hline \multirow[t]{2}{*}{$R_{\text {eco }}$} & $=95.37+1.6 \mathrm{LAI}_{\mathrm{sum}}{ }^{\mathrm{a}}$ & $\mathrm{LAI}_{\text {sum }}$ & 41.43 & 0.91 & $* *$ \\
\hline & $=-12.26+2.24 \mathrm{LAI}_{\text {sum }}+0.066\left(T_{a} \times \mathrm{AP}\right)^{\mathrm{b}}$ & $\mathrm{LAI}_{\mathrm{sum}}, T_{a} \times \mathrm{AP}$ & 22.76 & 0.98 & $* *$ \\
\hline \multirow[t]{2}{*}{ NEE } & $=188.32-946.83 S_{w}{ }^{\mathrm{a}}$ & $S_{w}$ & 38.66 & 0.85 & $* *$ \\
\hline & $=152.16-1.54\left(S_{w} \times \mathrm{AP}\right)^{\mathrm{b}}$ & $S_{w} \times \mathrm{AP}$ & 33.32 & 0.88 & $* *$ \\
\hline
\end{tabular}

Significance of the regressions $(P)$ are $\left({ }^{*}\right),\left({ }^{* *}\right)$, or $\left(^{* * *}\right)$ for $P<0.05,0.01$, and 0.001 , respectively.

a Only effects of single factor $\left(T_{a}, \mathrm{PAR}, S_{w}, \mathrm{AP}\right.$ and $\left.\mathrm{LAI}\right)$ were included in the multiple regression analysis.

b The interaction terms among $T_{a}$, PAR, $S_{w}$, AP and LAI were included in the multiple regression analysis. Symbol $(\times)$ indicates crossproduct of the variables.

was close to the 30-year average. The abundant precipitation at $\mathrm{HB}$ resulted in relatively high soil moisture content throughout the growing seasons, although the relatively less rain in the spring of 2004 caused a decrease in soil moisture, compared with 2005 (Fig. 2b). Although there was considerable precipitation at DX from June to August, soil moisture at DX was generally lower than that at HB (Fig. 2c), with higher seasonal fluctuation due to low vegetation coverage 
Table 4. Annual statistics of environmental factors and $\mathrm{CO}_{2}$ fluxes for the three grassland ecosystems during 2004-2005, including mean annual air temperature (MAT), annual precipitation (AP), mean annual water use efficiency (WUE), annual sums of net ecosystem exchange of $\mathrm{CO}_{2}(\mathrm{NEE})$, total ecosystem respiration $\left(R_{\mathrm{eco}}\right)$, and gross ecosystems production $(\mathrm{GEP}) . T_{g}$, PAR and LAI $\mathrm{L}_{\text {sum }}$ represent daily mean air temperature, daily mean PAR and accumulated leaf area index during growing season (from May to September), respectively.

\begin{tabular}{|c|c|c|c|c|c|c|c|c|c|c|}
\hline Site & Year & $\begin{array}{l}\text { MAT } \\
\left({ }^{\circ} \mathrm{C}\right)\end{array}$ & $\begin{array}{l}\mathrm{T}_{g} \\
\left({ }^{\circ} \mathrm{C}\right)\end{array}$ & $\begin{array}{c}\mathrm{AP} \\
(\mathrm{mm})\end{array}$ & $\begin{array}{c}\text { PAR } \\
\left(\mathrm{mol} \mathrm{m}^{-2} \mathrm{~d}^{-1}\right)\end{array}$ & $\begin{array}{c}\mathrm{LAI}_{\text {sum }} \\
\left(\mathrm{m}^{2} \mathrm{~m}^{-2}\right)\end{array}$ & $\begin{array}{l}\text { WUE }\left(\mathrm{g} \mathrm{C} \mathrm{Kg}^{-1}\right. \\
\left.\mathrm{H}_{2} \mathrm{O}\right)^{\mathrm{a}}\end{array}$ & $\begin{array}{c}\text { GEP } \\
\left(\mathrm{g} \mathrm{Cm}^{-2} \mathrm{yr}^{-1}\right)\end{array}$ & $\begin{array}{c}R_{\text {eco }} \\
\left(\mathrm{g} \mathrm{Cm}^{-2} \mathrm{yr}^{-1}\right)\end{array}$ & $\begin{array}{c}\text { NEE } \\
\left(\mathrm{g} \mathrm{Cm}^{-2} \mathrm{yr}^{-1}\right)\end{array}$ \\
\hline NMG & 2004 & 1.65 & 14.67 & 364.4 & 41.47 & 143.9 & 1.15 & -310.9 & 417.8 & 106.9 \\
\hline \multirow{2}{*}{ HB } & 2004 & -1.90 & 6.19 & 493.5 & 36.74 & 202.6 & 1.29 & -501.5 & 416.2 & -85.3 \\
\hline & 2005 & -1.31 & 7.18 & 541.5 & 36.47 & 225.5 & 1.38 & -553.9 & 502.2 & -51.7 \\
\hline
\end{tabular}

${ }^{a}$ Data from Hu et al. (2008).
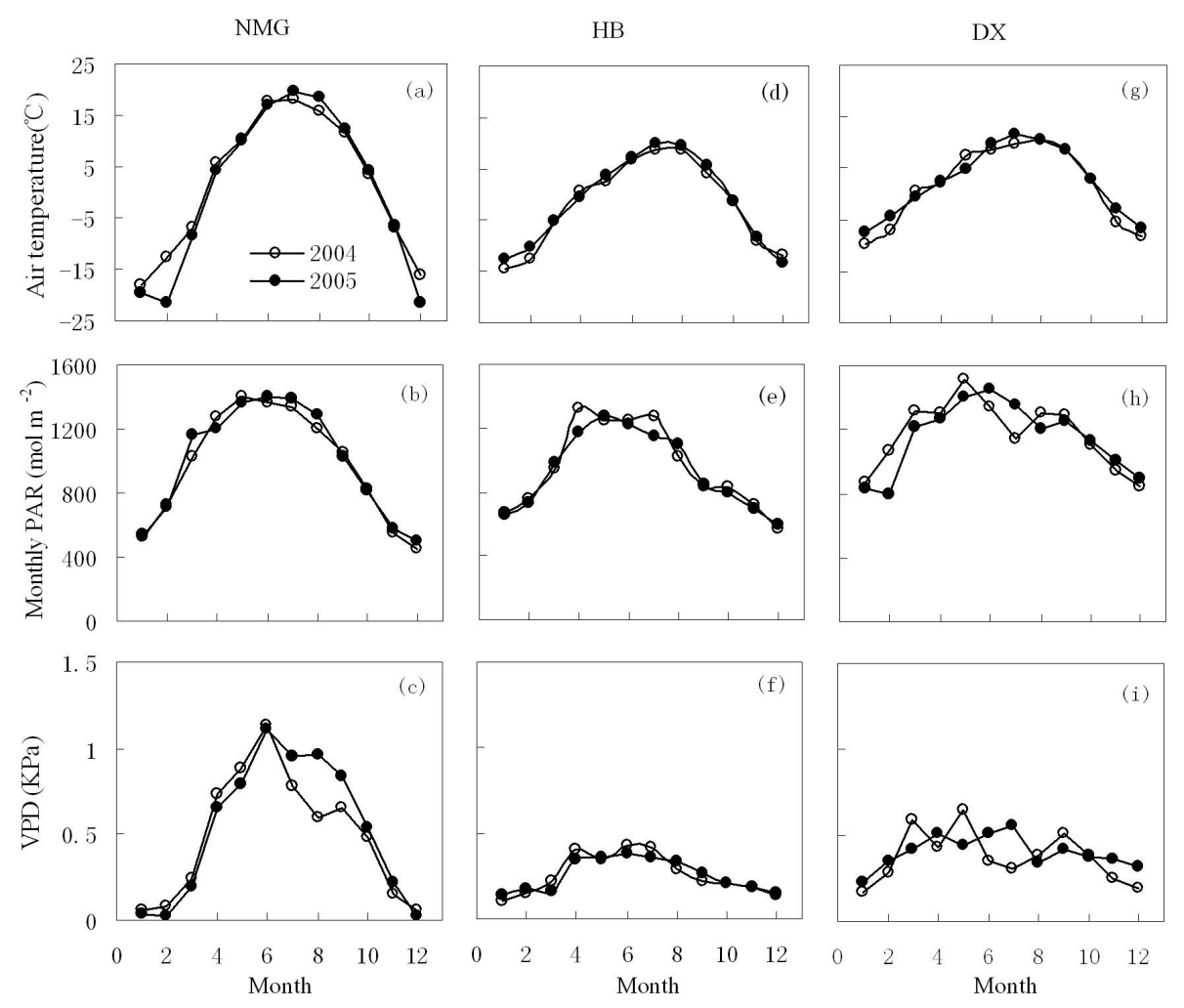

Fig. 1. Comparison of monthly photosynthetically active radiation (PAR), monthly mean air temperature $\left(T_{a}\right)$ and vapor pressure deficit (VPD) at the temperate steppe (NMG, a-c), the alpine shrub-meadow (HB, d-f) and the alpine steppe-meadow (DX, g-i) in 2004 and 2005.

and high surface evaporation induced by strong solar radiation (Shi et al., 2006; Hu et al., 2008). The VPD from May to September was highest at NMG and lowest at HB (Fig. 1c).

\subsection{Comparison of leaf area index}

The seasonal dynamics of LAI showed one-peak patterns at the three sites (Fig. 3). LAI at HB was generally higher than that at NMG and DX during the two growing seasons stud- ied. The LAI at HB in 2005 grew a half-month faster in the spring and also peaked a half-month earlier in summer than in 2004 (Fig. 3b). Although the peak value of LAI at HB in 2005 was $0.15 \mathrm{~m}^{2} \mathrm{~m}^{-2}$ lower than in 2004 , the accumulated

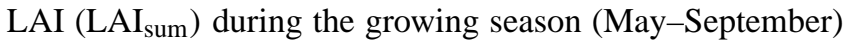
in 2005 was higher than that in 2004 (Table 4). The maximum LAI at DX occurred in late-August in both years, with LAI declining in 2005 due to less spring precipitation. The LAI at NMG reached a maximum of $1.58 \mathrm{~m}^{2} \mathrm{~m}^{-2}$ in 2004. 

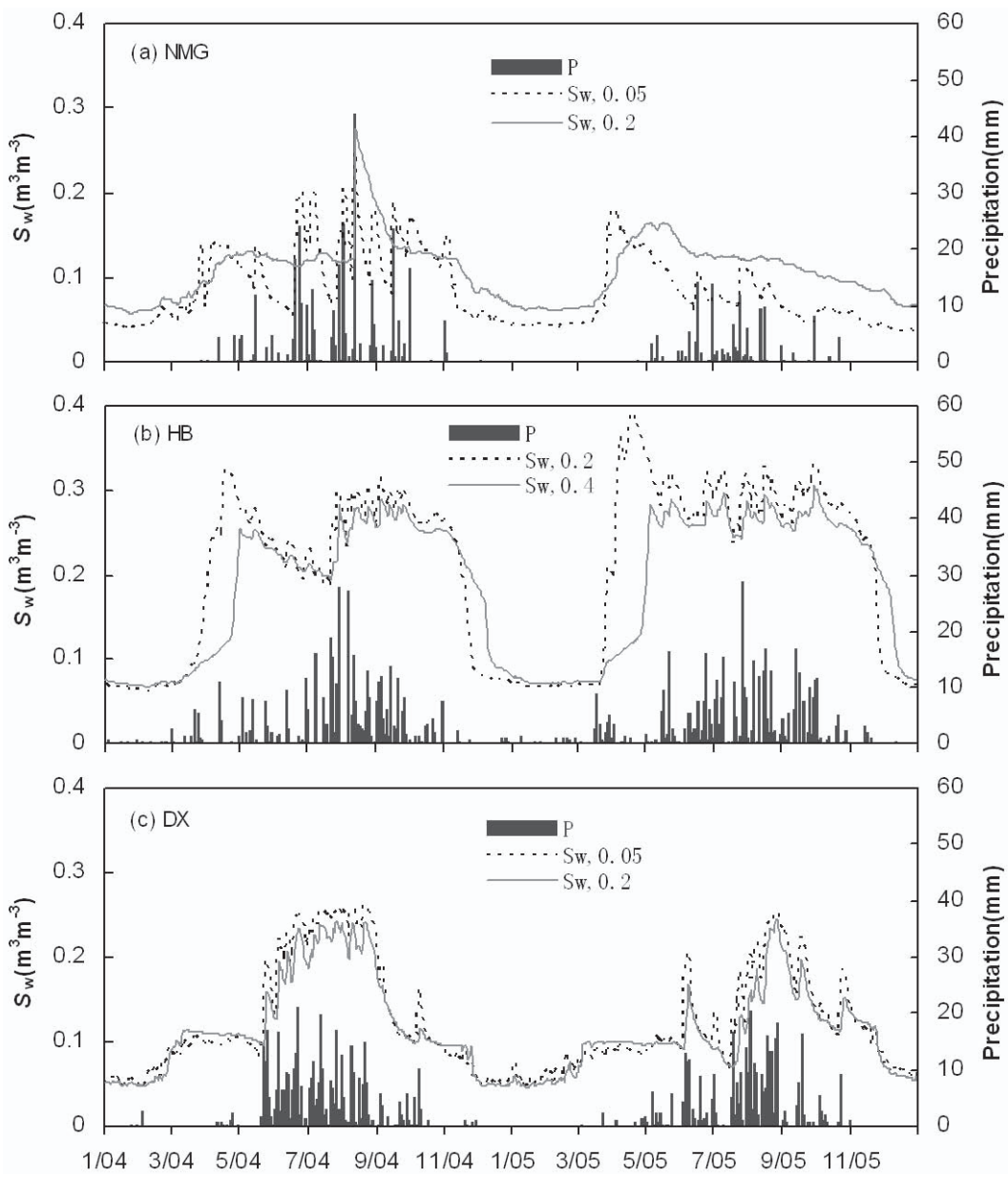

Fig. 2. Seasonal trends of daily total precipitation and daily average volumetric soil moisture $\left(S_{w}\right)$ at (a) NMG, (b) HB, and (c) DX in 2004 and 2005. Soil moisture was measured at 0.05 and $0.2 \mathrm{~m}$ depths at NMG and DX, 0.2 and $0.4 \mathrm{~m}$ depths at HB, respectively.

However, its LAI declined significantly in 2005 (Fig. 3), with maximum and accumulated LAI even lower than those at DX.

\subsection{Seasonality of $\mathrm{CO}_{2}$ fluxes at three grassland ecosys- tems}

The seasonal dynamics of GEP, $R_{\text {eco }}$, and NEE over the three grassland ecosystems during the two study years are shown in Fig. 4. The $\mathrm{CO}_{2}$ fluxes showed similar seasonal trends with that of air temperature at HB (Fig. 4b). Both the GEP and $R_{\text {eco }}$ increased rapidly beginning in early May and reached their peak values by mid/late-July through early August in both years, resulting in maximum net $\mathrm{CO}_{2}$ uptake in late July at HB (Fig. 4b). The daily maximum absolute value of GEP and $R_{\text {eco }}$ at HB was larger in the summer of 2005 than in 2004, although the daily values of NEE were comparable between the two years. The alpine shrub-meadow at $\mathrm{HB}$ was acting as net $\mathrm{CO}_{2}$ sink from the beginning of June through mid-September in both years, with net $\mathrm{CO}_{2}$ release during a few extremely rainy or cloudy days.
As compared to $\mathrm{HB}$, the $\mathrm{CO}_{2}$ fluxes at NMG tracked closely with rain events and soil moisture in the warm seasons. The NMG continued to release $\mathrm{CO}_{2}$ until late-June 2004 due to less precipitation from April through mid-June (Fig. 4a). The several critical rain events in late-June (18.3, 24 , and $10.5 \mathrm{~mm}$ on 20,22 , and 24 June, respectively) enhanced $R_{\text {eco }}$ faster than GEP, leading initially to an increase in net $\mathrm{CO}_{2}$ release and later, in early-July, to a shift from carbon source to carbon sink. During the second drought period in mid-July of 2004, the reduction in both GEP and $R_{\text {eco }}$ was apparent. The maximum net $\mathrm{CO}_{2}$ uptake occurred in late-August one week after the largest rainfall $(44 \mathrm{~mm}$ on 14 August, 2004), which sustained the steppe as a net $\mathrm{CO}_{2}$ uptake until mid-September. The temperate steppe at NMG shifted into net $\mathrm{CO}_{2}$ release in late September with the onset of grass senescence caused by decreasing fall temperatures. Both GEP and $R_{\text {eco }}$ at NMG in 2005 were significantly lower because of less precipitation during that summer, resulting in net $\mathrm{CO}_{2}$ release during almost the entire growing season (Fig. 4a). 

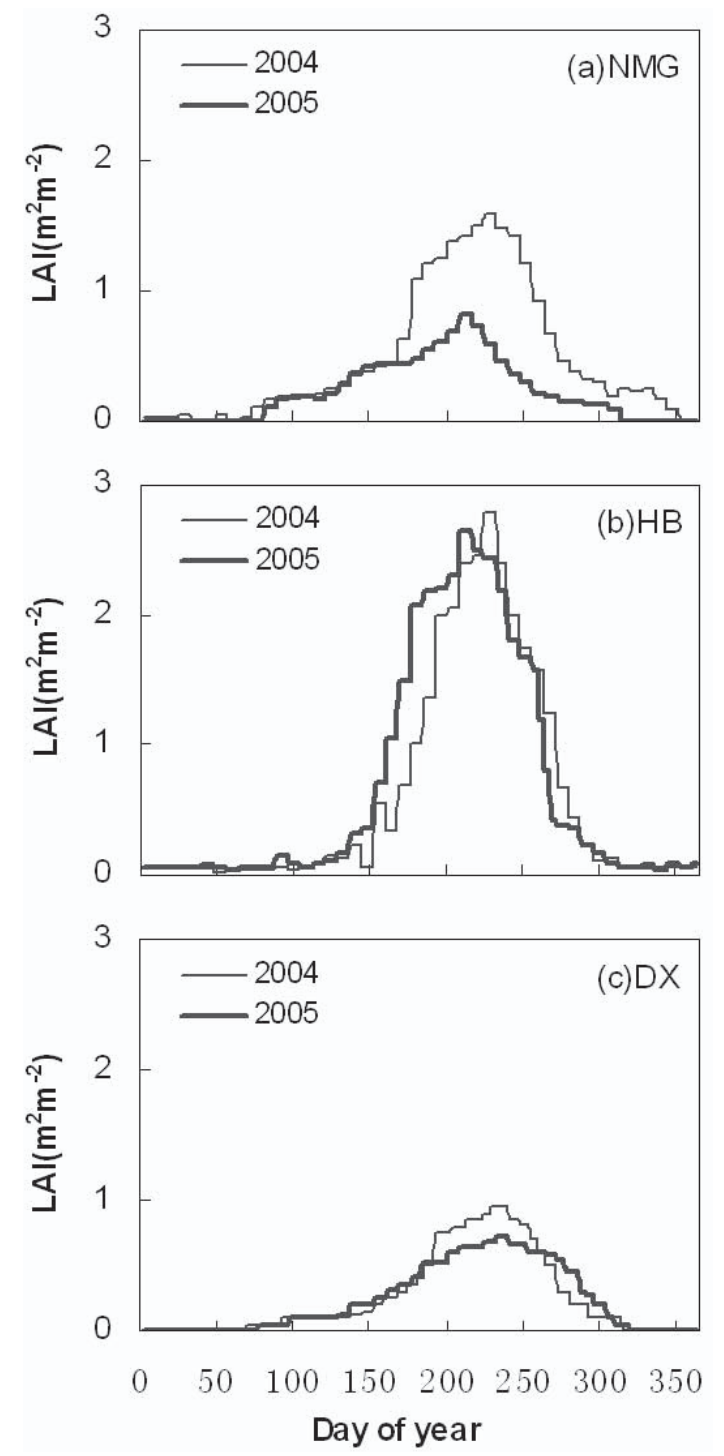

Fig. 3. Seasonal variation of leaf area index (LAI) at (a) NMG, (b) HB and (c) DX in 2004 and 2005.

The seasonality of GEP, $R_{\mathrm{eco}}$, and NEE at DX indicates their responses to the variation in both temperature and moisture. The magnitude of GEP, $R_{\text {eco }}$, and NEE in 2005 was generally less than those in 2004 . The $R_{\text {eco }}$ in 2004 reached relatively large values in early-July and maintained this level until early-September before grass senescence (Fig. 4c). However, the $R_{\text {eco }}$ peaked in mid-July 2005 and then declined steadily. The spring drought of 2005 also caused a 20-day delay in the ecosystem shift from carbon source to carbon sink. The peak daily values of GEP and NEE at DX were observed in early-July in 2004, but they were not observed until mid-August in 2005.
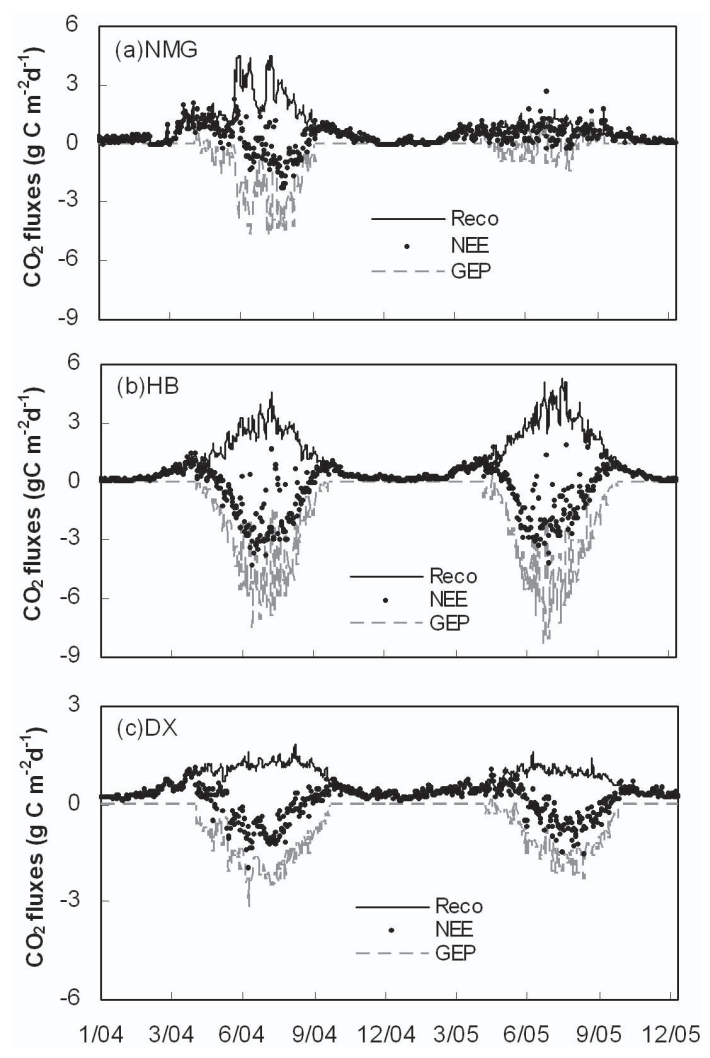

Fig. 4. Seasonal variation of daily integrated net ecosystem exchange of $\mathrm{CO}_{2}(\mathrm{NEE})$, ecosystem respiration $\left(R_{\mathrm{eco}}\right)$, and gross ecosystem production (GEP) at (a) NMG, (b) HB and (c) DX in 2004 and 2005.

\subsection{Annual $\mathrm{CO}_{2}$ budgets of three grasslands}

The annually integrated GEP, $R_{\text {eco }}$, and NEE for the three grassland ecosystems are presented in Table 4 . The alpine shrub-meadow at $\mathrm{HB}$ acted as a net $\mathrm{CO}_{2}$ sink, with a total accumulation of $-137 \mathrm{~g} \mathrm{C} \mathrm{m}^{-2}$ over the two study years. Although higher precipitation and temperature enhanced GEP in 2005, the enhancement of $R_{\text {eco }}$ was even larger, resulting in less net $\mathrm{CO}_{2}$ sequestration in 2005 than in 2004 at $\mathrm{HB}$ (Table 4). The DX and NMG were both acting as net $\mathrm{CO}_{2}$ source during the two years, with more $\mathrm{CO}_{2}$ release in relatively dry year of 2005 . Both GEP and $R_{\text {eco }}$ at NMG were significantly suppressed in 2005, which resulted primarily from less precipitation and reduced soil moisture during that growing season. The GEP and $R_{\text {eco }}$ at DX declined in 2005, which resulted primarily from the less spring precipitation in that year. The magnitude of annual sums of $\mathrm{CO}_{2}$ fluxes at $\mathrm{DX}$ was much smaller than those at $\mathrm{HB}$, although the two sites experienced comparable precipitation (Table 4). Our study also showed that both $R_{\text {eco }}$ and NEE were significant correlated with GEP at annual scale across the study sites and years (Fig. 5). 


\subsection{Relevant controls on seasonal variation in $R_{\mathrm{eco}}$, GEP, and NEE}

Figure 6 shows the relationship between soil temperature and ecosystem respiration ( $R_{\text {eco }}$ ), at NMG, HB, and DX in 2004 and 2005. The regression coefficients of the fitted curves are also presented in each plot. The eddy covariance measurements of the nighttime $R_{\text {eco }}$ were quite scattered. A bin width of one day with a minimum bin size of $n=5$ was used in the fitting procedure to reduce the effect of heteroscedasticity and to provide equal weighting in the parameter estimation (e.g., Griffis et al., 2003). Comparison of the response of $R_{\text {eco }}$ to soil temperature among the three grassland sites showed that most variation in $R_{\text {eco }}$ can be interpreted by the change in temperature, especially in the year or at the site with better moisture condition (e.g., at HB site in both years or at NMG site in 2004). Both the $R_{\text {eco }}$ at reference temperature $\left(R_{10}\right)$ and temperature sensitivity of $R_{\text {eco }}\left(Q_{10}\right)$ at $\mathrm{HB}$ were higher than those at DX and NMG. Figure 5 also shows that $R_{10}$ and $Q_{10}$ were reduced in the relatively dry year of 2005 at NMG and DX (Fig. 6b, f).

GEP is generally affected by radiation, temperature, and moisture conditions. We examined the relationship between $P_{\max }$ and environmental factors to understand the difference in determinant factor for the variation of GEP among the three sites. $P_{\max }$ values were derived from the MichaelisMenten equation using a 10-day data window from May to October for each site. Partial correlation analysis showed that air temperature explained $81 \%$ of the seasonal variation in $P_{\max }$ at HB $(P<0.05$, Fig. 7a). Howerve, about $50 \%$ of the variance in $P_{\max }$ at NMG and DX was ascribed to changes in soil moisture (Fig. 7b). Air temperature only explained $20 \%$ of the seasonal variation in $P_{\max }$ at DX $(P>0.05)$, whereas it had a negative effect on $P_{\max }$ at $\mathrm{NMG}\left(R^{2}=0.25\right.$, $P>0.05)$. This was mainly resulted from frequent summer drought at NMG, which leads to significant reduction in ecosystem photosynthesis under high radiation and temperature condition at moon time (Fu et al., 2006b). Figure 7b also indicates that the temperate steppe at NMG was much more sensitive to variation in soil moisture than the alpine meadow-steppe at DX in terms of increasing GEP and gaining $\mathrm{CO}_{2}$.

To differentiate the factors influencing the seasonal variation in $\mathrm{CO}_{2}$ fluxes among the three grassland sites, a multiple regression analysis was performed to assess the relationships of GEP, $R_{\text {eco }}$ or NEE with changes in environmental factors using monthly data during the growing seasons (Table 2). Results showed that seasonal variations in GEP, $R_{\text {eco }}$, and NEE at NMG significantly correlated with LAI $(P \leq 0.001$, Table 2$)$. The partial correlation coefficient (partial $R^{2}$ ) between GEP, $R_{\text {eco }}$, or NEE with other environmental factors were rather low $(<0.1)$, except that NEE also had an insignificant relationship with soil moisture $\left(R^{2}=0.4\right)$. However, the GEP, $R_{e c o}$, and NEE at HB significantly correlated with changes in air temperature $(P<0.001)$, which
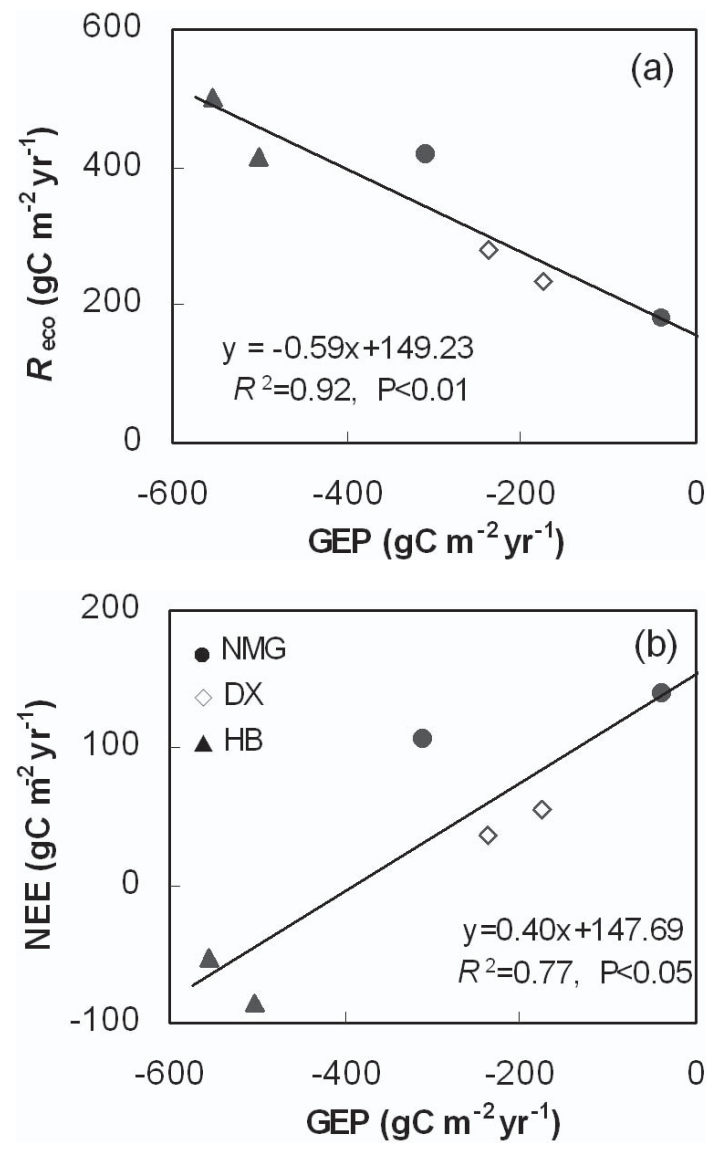

Fig. 5. Ecosystem respiration $\left(R_{\text {eco }}\right)$ and net ecosystem exchange of $\mathrm{CO}_{2}$ (NEE) verses gross ecosystem productivity (GEP) across the three sites in 2004 and 2005. The solid circle (•), hollow diamond $(\diamond)$ and solid triangle $(\boldsymbol{\Delta})$ represent the data of NMG, DX and HB, respectively.

explained $95 \%, 93 \%$ and $82 \%$ of the seasonal variation in NEE, GEP, and $R_{\text {eco }}$, respectively. Compared with NMG and HB, the GEP and NEE at DX were jointly affected by variations in soil moisture and air temperature. However, the $R_{\text {eco }}$ at DX was not significantly related to any of the listed factors under a 95\% confidence interval (Table 2). This result indicates the importance of soil water retention for $\mathrm{CO}_{2}$ sequestration at DX, despite the fact that its precipitation is comparable to that of $\mathrm{HB}$.

\subsection{Controlling factors for interannual and intersite variations in $\mathrm{CO}_{2}$ flux}

We also adopted the multiple regression analysis to access the relationship between annual $\mathrm{CO}_{2}$ budgets and environmental factors across the three sites and, further, to identify the prevailing factors and the underlying mechanisms that resulted in the interannual or intersite variation in $\mathrm{CO}_{2}$ flux. The stepwise multiple regression models are summarized in Table 3. The results show that LAI and soil moisture 

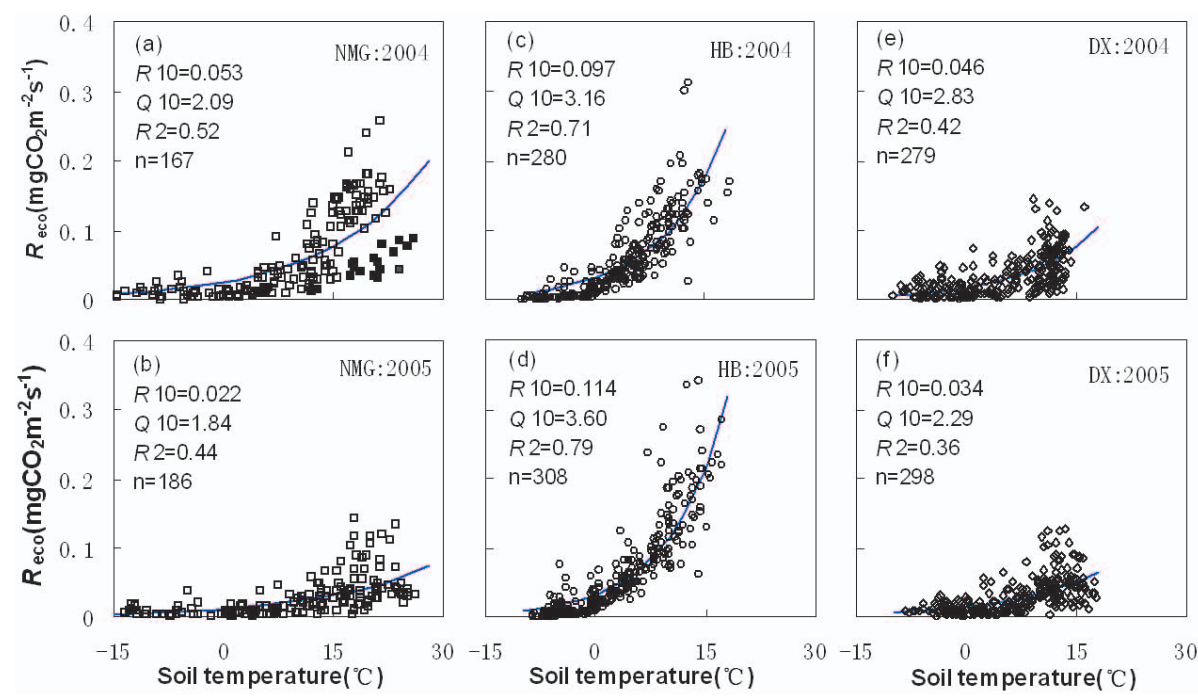

Fig. 6. The relationships between nighttime ecosystem respiration $\left(R_{\mathrm{eco}}\right)$ and soil temperature (at $5 \mathrm{~cm}$ depth) at NMG (a, b), HB (c, d) and DX (e, f) in 2004 and 2005. The solid diamonds plot (a) indicates the depression of $R_{\text {eco }}$ in drought period in 2004 at NMG.
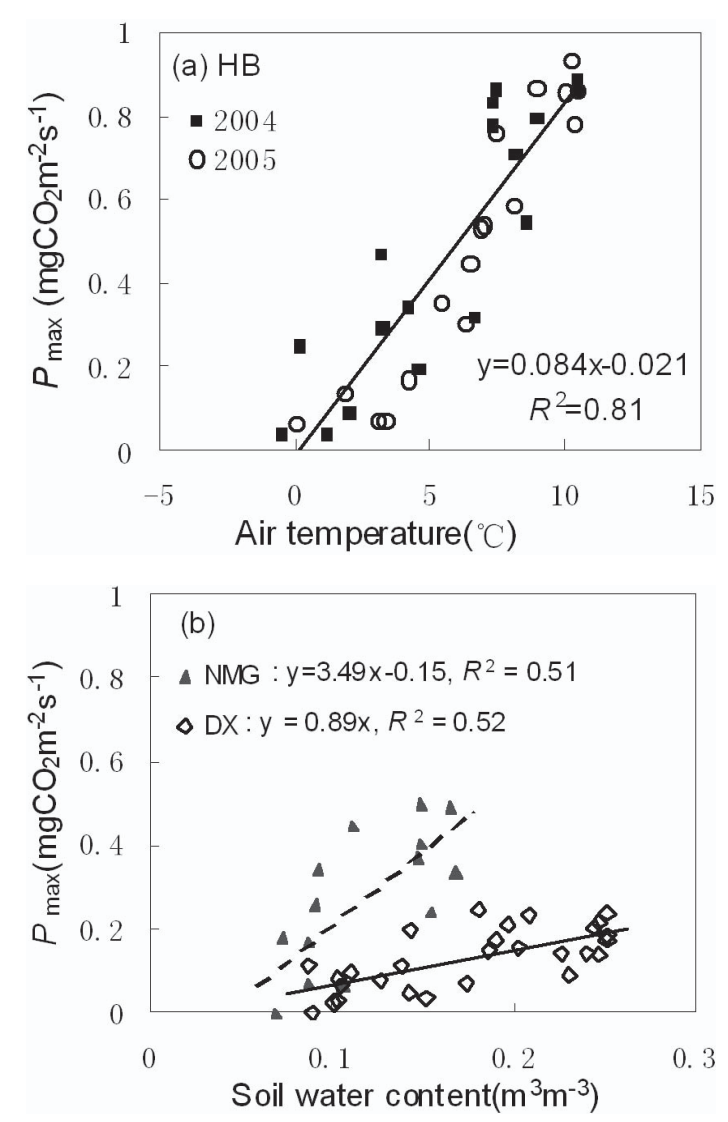

Fig. 7. The relationships between $P_{\max }$ and air temperature (for (a) $\mathrm{HB}$ ) and soil moisture (for (b) NMG and DX) during the growing season in 2004 and 2005. $P_{\max }$ values were derived from the rectangular hyperbolic model with a window of 10 days data. were the primary factors controlling the interannual and intersite variation in GEP, $R_{\text {eco }}$, and NEE (Fig. $8 \mathrm{a}$, d, and h, $P<0.01)$, when the effect of single factors $\left(T_{a}, \mathrm{PAR}, S_{w}\right.$, $P$, and LAI) were considered. However, when the interaction terms among $T_{a}$, PAR, $S_{w}, P$ and LAI were included in the multiple regression analysis, the interannual and intersite variation in GEP, $R_{\text {eco }}$, and NEE could be better explained by the joint effects of two or three variables (Table 3). With its prevailing influence on the interannual or intersite variation in GEP and $R_{\text {eco }}$, the accumulated leaf area index during the growing season $\left(\mathrm{LAI}_{\text {sum }}\right.$ ) was found to be significantly correlated with soil moisture other than annual precipitation (Fig. 9).

\section{Discussion}

\subsection{Comparison of ecosystem $\mathrm{CO}_{2}$ budget with other grasslands}

Although many studies have examined grassland $\mathrm{CO}_{2}$ fluxes based on eddy covariance measurements, large variability exists in the findings due to the diverse vegetation and climate types present in grassland ecosystems. Here, we selected the very limited works that have similar vegetation or climate types with our sites for comparison (Table 5). The annual $\mathrm{CO}_{2}$ release of the Leymus chinensis steppe at NMG is higher than of a temperate Stipa krylovii steppe, which is located in a neighboring area with similar climatic conditions and vegetation types (Wang et al., 2008). However, a grazed temperate steppe in Mongolia, which is located in the same climatic zone as the NMG site but with less mean annual precipitation, proved to be carbon neutral or a small carbon sink (Li et al., 2005). All of these studies have demonstrated that 
Table 5. Comparison of net ecosystem $\mathrm{CO}_{2}$ exchange (NEE) among different grassland ecosystems.

\begin{tabular}{|c|c|c|c|c|c|c|c|}
\hline Site & $\begin{array}{l}\text { Ecosystem } \\
\text { Type }\end{array}$ & Latitude & $\begin{array}{l}\text { Temperature } \\
\left({ }^{\circ} \mathrm{C}\right)\end{array}$ & $\begin{array}{l}\text { Precipitation } \\
(\mathrm{mm})\end{array}$ & $\begin{array}{l}\mathrm{NEE} \\
\left(\mathrm{gC} \mathrm{m}^{2} \mathrm{yr}^{-1}\right)\end{array}$ & Period & Source \\
\hline Lethbridge, Canada & Mixed grassland & $49^{\circ} 26^{\prime} \mathrm{N}$ & - & 401 & -109 to 18 & $1998-2000$ & Flanagan et al., 2002 \\
\hline KBU in Mongolia & Temperate steppe & $47^{\circ} 12.84^{\prime} \mathrm{N}$ & 1.2 & 196 & -41 & 2003 & Li et al., 2005 \\
\hline Great Plains, ND, USA & Mixed prairie & $46^{\circ} 46^{\prime} \mathrm{N}$ & - & 404 & -45 & 1999 & Frank and Dugas, 2001 \\
\hline Xilinhot, China & Temperate steppe & $44^{\circ} 08^{\prime} \mathrm{N}$ & 2 & 290 & 37 to 68 & 2004-2006 & Wang et al., 2008 \\
\hline NMG, China & Temperate steppe & $4^{\circ} 32^{\prime} \mathrm{N}$ & 1 & 350 & 107 to 140 & 2004-2005 & This study \\
\hline Monte Bondone, Italy & Subalpine grassland & $46^{\circ} 01^{\prime} \mathrm{N}$ & 5.5 & 1189 & -74.2 & 2004 & Gilmanov et al., 2007 \\
\hline Haibei, China & Alpine meadow & $37^{\circ} 36^{\prime} 48^{\prime \prime} \mathrm{N}$ & -1.7 & 561 & -193 to -79 & 2002-2004 & Kato et al., 2006 \\
\hline HB, China & Alpine shrub-meadow & $37^{\circ} 39^{\prime} 55^{\prime \prime} \mathbf{N}$ & -1.7 & 570 & -85 to -52 & 2004-2005 & This study \\
\hline Oklahoma, USA & Warm tallgrass prairie & $36^{\circ} 56^{\prime} \mathrm{N}$ & 14.0 & $\sim 1000$ & -46 to -274 & 1997-1999 & Suyker et al., 2003 \\
\hline DX, China & Alpine meadow-steppe & $30^{\circ} 51^{\prime} \mathrm{N}$ & 1.3 & 480 & 37 to 55 & 2004-2005 & This study \\
\hline Twize, New Zealand & Native tussock grassland & $44^{\circ} 14^{\prime} \mathrm{S}$ & 9.2 & 646 & -41 to 9 & 1999-2000 & Hunt et al., 2004 \\
\hline
\end{tabular}
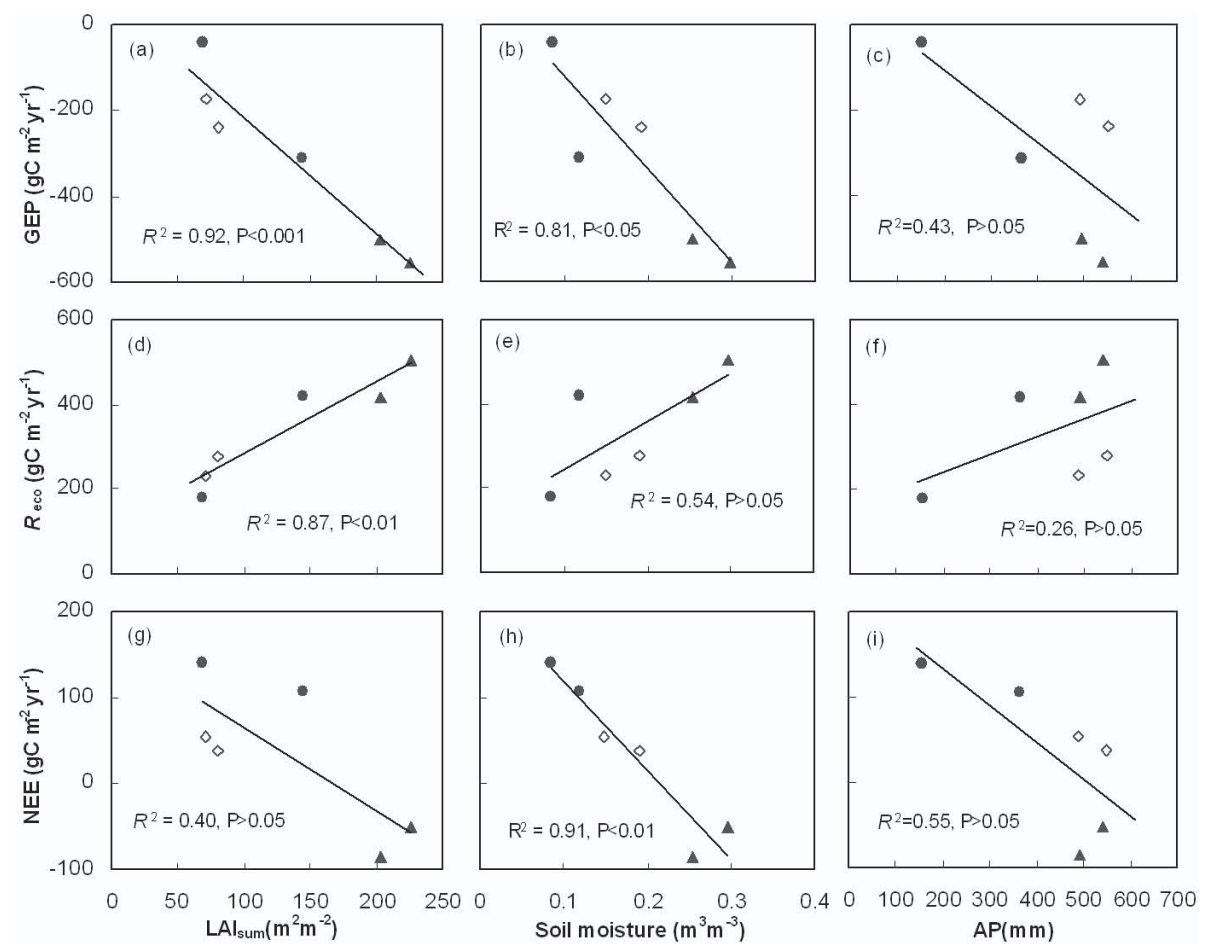

Fig. 8. Relationships between annual gross ecosystem production (GEP), ecosystem respiration $\left(R_{\mathrm{eco}}\right)$, and net ecosystem $\mathrm{CO}_{2}$ exchange (NEE) with accumulated Leaf area index from $\mathrm{LAI}_{\text {sum }}$, average volumetric soil moisture (from May to September), and annual precipitation (AP) across the three sites during 2004 and 2005. The solid circle $(\bullet)$, hollow diamond $(\diamond)$ and solid triangle $(\boldsymbol{\Delta})$ represent the data of NMG, $\mathrm{DX}$ and $\mathrm{HB}$, respectively.

limited precipitation and low soil moisture during the growing seasons are the primary environmental factors limiting the $\mathrm{CO}_{2}$ gain in the vast temperate steppe in Northern China and Mongolia ( $\mathrm{Li}$ et al, 2005; Fu et al., 2006a; Wang et al., 2008). The higher $\mathrm{CO}_{2}$ release from the NMG site might be ascribed to the larger amount of surface litter fall, which has resulted from more than 20 years of non-grazing and could contribute substantially to ecosystem respiration, especially during warm seasons.
Studies on $\mathrm{CO}_{2}$ fluxes in alpine meadows are very limited. The annual $\mathrm{CO}_{2}$ sink of the alpine shrub-meadow at $\mathrm{HB}$ was smaller than that of a neighboring alpine meadow with same temperature and precipitation (Kato et al., 2006), but comparable to a subalpine grassland in Italy, which has higher mean annual temperature and annual precipitation (Gilmanov et al., 2007). The magnitude of annual GEP and $R_{\text {eco }}$ over the alpine meadow-steppe at DX is much smaller than that of the alpine shrub-meadow at HB. The annual NEE in the alpine meadow-steppe at DX is close to that of the temperate 

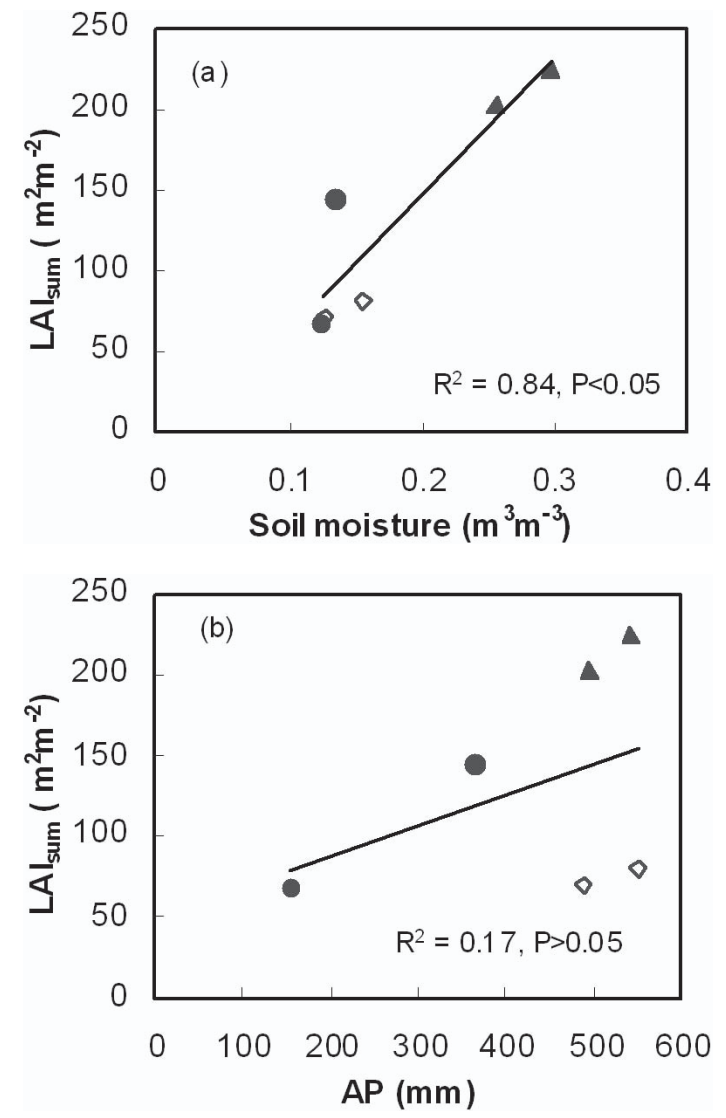

Fig. 9. Relationships between accumulated leaf area index (LAI $\mathrm{Lum}_{\text {sum }}$ and (a) soil moisture, (b) annual precipitation (AP) across the three sites in 2004 and 2005. The soil moisture value in plot (a) was the average soil moisture content at $0.2 \mathrm{~m}$ depth during the growing season (from May to September) at the three sites.

Stipa krylovii steppe in Inner Mongolia (Wang et al., 2008) and a tussock grassland in New Zealand (Hunt et al., 2004). The Qinghai-Tibet Plateau is a very special biogeographical unit due to its high altitude extending over a large area, and it possesses a variety of alpine ecosystems that experience different temperature and precipitation regimes (Zhao and Zhou, 1999). Relatively lower temperature and frequent precipitation during the growing season create a cold and humid climate over the area around HB site, which nurtures highly productive alpine-meadow vegetation. However, the DX site is situated above $4000 \mathrm{~m}$, where relatively low vegetation coverage (Table 1) and lower soil moisture result from high surface evaporation induced by strong solar radiation are not favorable for $\mathrm{CO}_{2}$ uptake (Shi et al., 2006; Hu et al., 2008).

Generally, the annual $\mathrm{CO}_{2}$ uptake in the three grasslands of this study was smaller than that of the warm tall-grass prairies in North America, which experience higher temperatures and more precipitation (Flanagan et al., 2002; Suyker et al., 2003), and that of the intensively managed grasslands in central and northern Europe (Gilmanov et al., 2007).

\subsection{Environmental controls on seasonal variation in grassland $\mathrm{CO}_{2}$ fluxes}

Our study showed that the controlling factors for season variations in $\mathrm{CO}_{2}$ fluxes were different for NMG, $\mathrm{HB}$, and DX. LAI dominated the seasonal variation in $\mathrm{CO}_{2}$ fluxes (GEP, $R_{\text {eco }}$ and NEE) at NMG, and air temperature was the primary factor affecting the seasonal variation in $\mathrm{CO}_{2}$ fluxes at HB (Table 2). In this case, our findings differ from previous studies, which generally demonstrate that soil moisture content is the primary factor controlling seasonal and interannual variation in $\mathrm{CO}_{2}$ fluxes in different grasslands (Flanagan et al., 2002; Suyker et al., 2003; Ma et al., 2007; Wang et al., 2008). Our results for the temperate steppe at NMG agree with those of Li et al. (2005), who found that the seasonal variation in NEE and GEP of a temperate steppe during the growing season was primarily influenced by LAI and precipitation. Actually, there is great agreement among these results since soil moisture content usually correlated positively with LAI, especially in those grasslands that frequently experienced drought (Flanagan et al., 2002). For the NMG site in our study, a significant positive linear relationship between LAI and precipitation $\left(R^{2}=0.72, P<0.01\right)$ or soil moisture $\left(R^{2}=0.68, P<0.01\right)$ also existed at monthly time scale. This indicates the underlying effects of precipitation and soil moisture on $\mathrm{CO}_{2}$ fluxes at NMG, as a result of their influence on LAI development.

Unlike at the NMG site, soil moisture availability was not a limiting factor for the grass growth at $\mathrm{HB}$, where sufficient precipitation fell almost evenly through the growing season. In this case, temperature had a more significant influence on $\mathrm{CO}_{2}$ flux dynamics, as is often the case with ecosystems that experience low temperatures and high humidity, such as tundra (Harazono et al., 2003) and alpine meadows (Kato et al., 2006). Our results also demonstrated the dominant influence of air temperature on ecosystem photosynthesis (Fig. 7a) and respiration (Fig. 6a, b) at HB. The higher temperatures at HB in May and June in 2005 induced an early increase of LAI and a longer duration of high LAI values (Fig. 3), which caused a larger GEP in 2005. However, the enhancement of $R_{\text {eco }}$ by higher temperatures from May throughout September in 2005 was larger, which resulted in less net $\mathrm{CO}_{2}$ uptake in that year. As a result, the difference in GEP, $R_{\text {eco }}$, and NEE at HB site between the two study years resulted primarily from the influence of variations in temperature. Here, our results agree well previous study that suggested that $\mathrm{CO}_{2}$ fluxes in alpine meadows are largely influenced by temperature (Kato et al., 2006).

Our results showed that the seasonal variation in $\mathrm{CO}_{2}$ fluxes at DX was caused by the combined effects of air temperature and soil moisture. The ecosystem activity at DX, as an alpine grassland, was potentially affected by low temperatures (Harazono et al., 2003), although air temperature at the DX site was $2^{\circ} \mathrm{C}$ higher than that at $\mathrm{HB}$ (Fig. 1, Table 4). However, soil moisture during the growing seasons 
at DX was much lower than that at $\mathrm{HB}$ (Fig. 2), despite the comparable levels of precipitation at these two alpine sites. Furthermore, the high gravel content in the soil at DX also limited the soil's ability to retain water (Shi et al., 2006). As a result, the seasonal variation in GEP and NEE at DX was significantly correlated both to soil moisture and air temperature, with a higher partial correlation with soil moisture (Table 2). This finding indicates the characteristic of this alpine meadow-steppe as a transitional vegetation type between meadow and steppe. Although we didn't find an obvious relationship between $R_{\text {eco }}$ and any of the concerned factors at the monthly scale (Table 2), $R_{\text {eco }}$ at DX was still influenced simultaneously by soil temperature and soil moisture at hourly time scale (Shi et al., 2006).

\subsection{Effect of LAI on interannual and intersite variations in ecosystem $\mathrm{CO}_{2}$ budgets}

Although many studies have addressed the environmental influences on $\mathrm{CO}_{2}$ fluxes in various grasslands, few have sought to understand the dominant biotic or abiotic factors that control the grassland ecosystem $\mathrm{CO}_{2}$ budget at a regional scale. A synthesis study across 20 European grasslands by Gilmanov et al. (2007) suggested the relationship of grassland GEP and $R_{\text {eco }}$ with macroclimatic factors (mainly precipitation and temperature), which cannot be expressed by simple monofactorial models. Our results showed that soil moisture was the dominant factor influencing interannual and intersite variation in NEE across the study sites and years (Table 3 and Fig. 8h), which is consistent with the findings of many earlier studies conducted at individual sites (Flanagan et al., 2002; Suyker et al., 2003; Hunt et al., 2004). We also found that LAI (especially when calculated as the accumulated LAI during growing season, or $\mathrm{LAI}_{\text {sum }}$ ) plays a key role in the difference in annual GEP and $R_{\text {eco }}$ among sites or years (Fig. 8, Table 3). This finding differed from our hypothesis that the interannual and intersite variations in GEP of grassland ecosystems would mainly correlate with the variation in annual precipitation, which has been suggested by many previous studies on individual sites ( $\mathrm{Li}$ et al., 2005; Ma et al., 2007; Gilmanov et al., 2007). Flanagan et al. (2002) also found a strong correlation between the GEP and LAI in temperate grasslands. Here, however, the role of LAI could be explained by the significant positive correlation between LAI and averaged soil moisture during the growing season across the study sites and years (Fig. 9a). It confirmed our speculation that variation in LAI is an integrative indicator of grassland plant growth in response to concurrent changes in multi-environmental factors (including air temperature, PAR, VPD, soil moisture, precipitation, etc.), of which soil moisture is usually the most significant influence. The poor relationship between LAI and precipitation among our sites (Fig. 9b) suggested the importance of available moisture other than gross precipitation on grass growth and $\mathrm{CO}_{2}$ uptake in grasslands. On the other hand, the difference in LAI at the regional scale, to some extent, also indicates the difference of vegetation types or biome types, which were determined by long-term climatic and geobiological environments. In our study, the three sites represent three different vegetation types. The significant relationship between LAI and GEP across the three sites suggests the reliability of estimating GEP of grasslands from LAI at regional scale.

The significant relationship between annual $R_{\text {eco }}$ and LAI across the study sites and years could be ascribed to the strong dependence of $R_{\text {eco }}$ on GEP (Fig. 5a). Although there might be some artificial mechanism in the relationship between $R_{\text {eco }}$ and GEP due to the partitioning of GEP and $R_{\text {eco }}$ from eddy covariance derived NEE, we cannot deny the strong influence of canopy photosynthesis on $R_{\text {eco }}$ by providing the substrate availability for autotrophic respiration and heterotrophic respiration (Davidson et al., 2006). Evidence exists in the literatures pertaining to the similar relationship between $R_{\text {eco }}$ and GEP for many ecosystem types (Valentini et al., 2000; Law et al., 2002; Li et al., 2005, Aires et al., 2008), suggesting the shadowing effect of canopy photosynthesis activity on ecosystem respiration.

\section{Conclusions}

This study compared the $\mathrm{CO}_{2}$ fluxes (GEP, $R_{\text {eco }}$, and NEE) over three grasslands in China and analyzed the relevant factors influencing them. During the two study years, the alpine shrub-meadow acted as a net $\mathrm{CO}_{2}$ sink, whereas the temperate steppe and the alpine meadow-steppe acted as net $\mathrm{CO}_{2}$ sources. We found that the dominant factors influencing seasonal variation in $\mathrm{CO}_{2}$ fluxes were different among the three grasslands. LAI was the primary factor controlling the seasonal variations in GEP, $R_{\mathrm{eco}}$, and NEE of the temperate steppe, whereas air temperature exerted the dominant influences over variations in GEP $R_{\text {eco }}$, and NEE of the alpine shrub-meadow. The seasonal variation in $\mathrm{CO}_{2}$ fluxes of the alpine meadow-steppe was jointly affected by air temperature and soil moisture. The annual GEP and $R_{\text {eco }}$ significantly correlated with accumulated LAI across the study sites and years, whereas soil moisture accounts for the variation in annual NEE among the six site-years. The significantly positive relationship between accumulated LAI and average soil moisture content led us to conclude that available soil moisture remains the primary factor influencing the spatial variation in net $\mathrm{CO}_{2}$ exchange in grassland ecosystems.

Acknowledgements. This study was supported in part by the Knowledge Innovation Program of the Chinese Academy of Sciences (Grant No. KZCX2-YW-432) and the National Natural Science Foundation of China (Grants No. 30700110, 30721140307 , and 30590381). Other sources of support included the Frontier Program of the Institute of Geographic Sciences and Natural Resources Research (Grant No. O66U0604SZ) and the "HundredTalents" Program of the Chinese Academy of Sciences 
(CXTD-Z2005-1). We gratefully acknowledge the anonymous reviewers for providing constructive comments, which were very helpful for the improvement of on our manuscript. Special thanks go to David C. Brill (from Institute for a Secure and Sustainable Environment, The University of Tennessee) for revising the English writing of our manuscript.

Edited by: G. Wohlfahrt

\section{References}

Adams, J. M., Faure, H., Faure-Denard, L., McGlad, J. M., and Woodward, F. I.: Increases in terrestrial carbon storage from the last glacial maximum to the present, Nature, 348, 711-714, 1990.

Aires, L. M. I., Pio, C. A., and Pereira, J. S.: Carbon dioxide exchange above a Mediterranean $\mathrm{C}_{3} / \mathrm{C}_{4}$ grassland during two climatologically contrasting years, Glob. Change Biol., 14, 539$555,2008$.

Aubinet, M., Grelle, A., Ibrom, A., Rannik, U., Moncrieff, J., Foken, T., Kowalski, P., Martin, P., Berbigier, P., Bernhofer, C., Clement, R., Elbers, J., Granier, A., Grunwald, T., Morgenster, K., Pilegaard, K., Rebmann, C., Snijders, W., Valentini, R., and Vesala, T.: Estimates of the annual net carbon and water exchange of European forests: the EUROFLUX methodology, Adv. Ecol. Res., 30, 113-174, 2000.

Chen, Z. Z., Wang, S. P., and Wang, Y. F.: Update progress on grassland ecosystem research in Inner Mongolia steppe, Chinese Bull. Botany, 20, 423-429, 2003.

Davidson, E. A., Janssens, I. A., and Luo, Y. Q.: On the variability of respiration in terrestrial ecosystems: moving beyond $Q_{10}$, Glob. Change Biol., 12, 154-164, 2006.

Derner, J. D., Boutton, T. W., and Briske, D. D.: Grazing and ecosystem carbon storage in the North American Great Plains, Plant Soil, 280, 77-90, 2006.

Falge, E., Baldocchi, D., Olson, R., Anthoni, P., Aubinet, M., Bernhofer, C., Burba, G., Ceulemans, R., Clement, R., Dolmani, H., Granier, A., Gross, P., Grünwald, T., Hollinger, D., Jensen, N.O., Katul, G., Keronen, P., Kowalski, A., Lai, C. T., Law, B. E., Meyers, T., Moncrieff, J., Moors, E., Munger, J. W., Pilegaard, K., Rannik, Ü., Rebmann, C., Suyker, A., Tenhunen, J., Tu, K., Verma, S., Vesala, T., Wilson, K., and Wofsy, S.: Gap filling strategies for defensible annual sums of net ecosystem exchange, Agr. Forest Meteorol., 107, 43-69, 2001.

Fan, J. W., Zhong, H. P., Harris, W., Yu, G. R., Wang, S. Q., $\mathrm{Hu}, \mathrm{Z}$. M., and Yue, Y. Z.: Carbon storage in the grasslands of China based on field measurements of above- and below-ground biomass, Climatic Change, 86, 375-396, 2008.

Flanagan, L. B., Linda, L. A., and Carlson, P. J.: Seasonal and interannual variation in carbon dioxide exchange and carbon balance in a northern temperate grassland, Glob. Change Biol., 8, 599615, 2002.

Frank, A. B. and Dugas, W. A.: Carbon dioxide fluxes over a northern semiarid, mixed-grass prairie, Agr. Forest Meteorol., 108, 317-326, 2001.

Fu, Y. L., Yu, G. R., Wang, Y. F., LI, Z. Q., and Hao, Y. B.: Effect of water stress on ecosystem photosynthesis and respiration of a Leymus chinensis steppe in Inner Mongolia, Sci. China, Ser. D, 49(Suppl.II), 196-206, 2006a.
Fu, Y. L., Yu, G. R., Sun, X. M., Li, Y. N., Wen, X. F., Zhang, L. M., LI, Z. Q., Zhao, L., and Hao, Y. B.: Depression of net ecosystem $\mathrm{CO}_{2}$ exchange in semi-arid Leymus chinensis steppe and alpine shrub, Agr. Forest Meteorol., 67, 293-321, 2006b.

Gilmanov, T. G., Soussana, J. F., Aires, L., Allard, V., Ammann, C., Balzarolo, M., Barcza, Z., Bernhofer, C., Campbell, C. L., Cernusca, A., Cescatti, A., Clifton-Brown, J., Dirks, B. O. M., Dore, S., Eugster, W., Fuhrer, J., Gimeno, C., Gruenwald, T., Haszpra, L., Hensen, A., Ibrom, A., Jacobs, A. F. G., Jones, M. B., Lanigan, G., Laurila, T., Lohila, A., Manca, G., Marcolla, B., Nagy, Z., Pilegaard, K., Pinter, K., Pio, C., Raschi, A., Rogiers, N., Sanz, M. J., Stefani, P., Sutton, M., Tuba, Z., Valentini, R., Williams, M. L., and Wohlfahrt, G.: Partitioning European grassland net ecosystem $\mathrm{CO}_{2}$ exchange into gross primary productivity and ecosystem respiration using light response function analysis, Agr. Ecosyst. Environ., 121, 93-120, 2007.

Griffis, T. J., Black, T. A., Morgenstern, K., Barr, A. G., Nesic, Z., Drewitt, G. B., Gaumont-Guay, D., and McCaughey, J. H.: Ecophysiological controls on the carbon balances of three southern boreal forests, Agr. Forest Meteorol., 117, 53-71, 2003.

Hao, Y., Wang, Y., Huang, X., Cui, X., Zhou, X., Wang, S., Niu, H., and Jiang, G.: Seasonal and interannual variation in water vapor and energy exchange over a typical steppe in Inner Mongolia, China, Agr. Forest Meteorol., 146, 57-69, 2007.

Harazono, Y., Mano, M., Miyata, A., et al.: Inter-annual carbon dioxide uptake of a wet sedge tundra ecosystem in the Arctic, Tellus, 55B, 215-231, 2003.

Hu, Z. M., Yu, G. R., Fu, Y. L., Sun, X. M., Li, Y. N., Shi, P. L., Wang, Y. F., and Zheng, Z. M.: Effects of vegetation control on ecosystem water use efficiency within and among four grassland ecosystems in China, Glob. Change Biol., 14, 1609-1619, 2008.

Hunt, J. E., Kelliher, F. M., Mcseveny, T. M., Ross, D. J., and Whitehead, D.: Long-term carbon exchange in a sparse, seasonally dry tussock grassland, Glob. Change Biol., 10, 1785-1800, 2004.

IPCC, Climate Change 2001: The Scientific Basis. Cambridge University Press, Cambridge, UK, 2001.

Kato, T., Tang, Y., Gu, S., Cui, X. Y., Hirota, M., Du, M. Y., Li, Y. N., Zhao, X. Q., and Oikawa, T.: Carbon dioxide exchange between the atmosphere and an alpine meadow ecosystem on the Qinghai-Tibetan Plateau, China, Agr. Forest Meteorol., 124, 121-134, 2004.

Kato, T., Tang, Y., Gu, S., Hirano, T., Du, M., Li, Y., and Zhao, L.: Temperature and biomass influences on interannual changes in $\mathrm{CO}_{2}$ exchange in an alpine meadow on the Qinghai-Tibetan Plateau, Glob. Change Biol., 12, 1285-1298, 2006.

Knapp, A. K., Fay, P. A., Blair, J. M., Collins, S. L., Smith, M. D., Carlisle, J. D., Harper, C. W., Danner, B. T., Lett, M. S., and McCarron, J. K.: Rainfall variability, carbon cycling, and plant species diversity in a mesic grassland, Science, 298, 2202-2205, 2002.

Law, B. E., Falge, E., Gu, L., Baldocchi, D. D., Bakwin, P., Berbigier, P., Davis, K., Dolman, A. J., Falk, M., Fuentes, J. D., Goldstein, A., Granier, A., Grelle, A., Hollinger, D., Janssens, I. A., Jarvis, P., Jensen, N. O., Katul, G., Mahli, Y., Matteucci, G., Meyers, T., Monson, R., Munger, W., Oechel, W., Olson, R., Pilegaard, K., Paw U, K. T., Thorgeirsson, H., Valentini, R., Verma, S., Vesala, T., Wilson, K., and Wofsy, S.: Environmental controls over carbon dioxide and water vapor exchange of terrestrial vegetation, Agr. Forest Meteorol., 113, 97-120, 2002. 
Li, L., Liu, X., and Chen, Z.: Study on the carbon cycle of Leymus chinensis steppe in the Xilin River basin, Acta Botanica Sinca, 40, 955-961, 1998.

Li, S. G., Asanuma, J., Eugster, W., Kotani, A., Liu, J. J., Urano, T., Oikawa, T., Davaa, G., Oyunbaatar, D., and Sugita, M.: Net ecosystem carbon dioxide exchange over grazed steppe in central Mongolia, Glob. Change Biol., 11, 1941-1955, 2005.

Lloyd, J. and Taylor, J. A.: On the temperature dependence of soil respiration, Funct. Ecol., 8, 315-323, 1994.

Ma, S. Y., Baldocchi, D. D., Xu, L. K., and Hehn, T.: Inter-annual variability in carbon dioxide exchange of an oak/grass savanna and open grassland in California, Agr. Forest Meteorol., 147, 157-171, 2007.

Massman, W. J. and Lee, X.: Eddy covariance flux corrections and uUncertainties in long term studies of carbon and energy exchanges, Agr. Forest Meteorol., 113, 121-144, 2002.

McCarthy, J., Canziani, O., Leary, N., Dokken, D., and White, K. (eds.).: Climate Change 2001: Impacts, Adaptation and Vulnerability, Cambridge University Press, Cambridge, UK, 2001.

$\mathrm{Ni}$, J.: Carbon storage in grasslands of China, J. Arid Environ., 50, 205-218, 2002.

Niu, S., Wu. M., Han, Y., Xia, J., Li, L., and Wan, S.:Watermediated responses of ecosystem carbon fluxes to climatic change in a temperate steppe, New Phytol., 177, 209-219, 2008.

Novick, K. A., Story, P. C., Katul, G. G., Ellsworth, D. S., Siqueira, M. B. S., Juang, J., and Oren, R.: Carbon dioxide and water vapor exchange in a warm temperate grassland, Oecologia, 138, 259-274, 2004.

Pacala, S. W., Hurtt, G. C., Baker, D., Peylin, P., Houghton, R. A., Birdsey, R. A., Heath, L., Sundquist, E. T., Stallard, R. F., Ciais, P., Moorcroft, P., Caspersen, J. P., Shevliakova, E., Moore, B., Kohlmaier, G., Holland, E., Gloor, M., Harmon, M. E., Fan, S.M., Sarmeinto, J. L., Goodale, C. L., Schimel, D., and Field, C. B.: Consistent land- and atmosphere-based US carbon sink estimates, Science, 292, 2316-2320, 2001.

Reichstein, M., Falge, E., Baldocchi, D., Papale, D., Aubinet, M., Berbigier, P., Bernhofer, C., Buchmann, N., Gilmanov, T., Granier, A., Grünwald, T., Havránková, K., Ilvesniemi, H., Janous, D., Knohl, A., Laurila, T., Lohila, A., Loustau, D., Matteucci, G., Meyers, T., Miglietta, F., Ourcival, J. M., Pumpanen, J., Rambal, S., Rotenberg, E., Sanz, M., Tenhunen, J., Seufert, G., Vaccari, F., Vesala, T., Yakir, D., and Valentini, R.: On the separation of net ecosystem exchange into assimilation and ecosystem respiration: review and improve algorithm, Glob. Change Biol., 11, 1424-1439, 2005.

Shi, P. L., Sun, X. M., Xu, L. L., Zhang, X. Z., He, Y. T., Zhang, D. Q., and $\mathrm{Yu}, \mathrm{G}$. R.: Net ecosystem $\mathrm{CO}_{2}$ exchange and controlling factors in a stepp-Kobresia meadow on the Tibetan Plateau, Sci. China, Ser. D, 49(Suppl.II), 207-218, 2006.

Suyker, A., Verma, S., and Burba, G.: Interannual variability in net $\mathrm{CO}_{2}$ exchange of a native tallgrass prairie, Glob. Change Biol., 9, 255-265, 2003.
Valentini, R., Matteucci, G., Dolman, A. J., Schulze, E. D., Rebmann, C., Moors, E. J., Granier, A., Gross, P., Jensen, N. O., Pilegaard, K., Lindroth, A., Grelle, A., Bernhofer, C., Grunwald, T., Aubinet, M., Ceulemans, R., Kowalski, A. S., Vesala, T., Rannik, U., Berbigier, P., Loustau, D., Gumundsson, J., Thorgeirsson, H., Ibrom, A., Morgenstern, K., Clement, R., Moncrieff, J., Montagnani, L., Minerbi, S., and Jarvis, P. G.: Respiration as the main determinant of carbon balance in European forests, Nature, 404, 861-865, 2000.

Verburg, P. S. J., Arnone, J. A., Obrist, D., Schorran, D. E., Evans, R. D., Leroux-Swarthout, D., Johnson, D. W., Luos, Y., and Coleman, J. S.: Net ecosystem carbon exchange in two grassland ecosystems, Glob.Change Biol., 10, 498-508, 2004.

Wang, Y., Zhou, G., and Wang, Y.: Environmental effects on net ecosystem $\mathrm{CO}_{2}$ exchange at half-hour and month scales over Stipa krylovii steppe in northern China, Agr. Forest Meteorol., 148, 714-722, 2008.

Wang, G. X., Cheng, G. D., and Shen, Y. P.: Soil organic carbon pool of grasslands on the Tibetan Plateau and its global implication, J. Glaciol. Geocryol., 24, 693-700, 2002 (in Chinese).

Webb, E. K., Pearman, G. I., and Leuning, R.: Correction of flux measurement for density effects due to heat and water vapour transfer, Q. J. Roy. Meteorol. Soc., 106, 85-100, 1980.

Wever, L. A., Flanagan, L. B., and Carlson, P. J.: Seasonal and interannual variation in evapotranspiration, energy balance and surface conductance in a northern temperate grassland, Agr. Forest Meteorol., 112, 31-49, 2002.

Wilczak, J. M., Oncley, S. P., and Stage, S. A.: Sonic anemometer tilted correction algorithms, Bound.-Lay. Meteorol., 99, 127150, 2001.

Wohlfahrt, G., Anfang, C., Bahn, M., Haslwanter, A., Newesely, C., Schmitt, M., Drösler, M., Pfadenhauer, J., and Cernusca, A.: Quantifying nighttime ecosystem respiration of a meadow using eddy covariance, chambers and modeling, Agr. Forest Meteorol., 128, 141-162, 2005.

Xu, L. K. and Baldocchi, D. D.: Seasonal variation in carbon dioxide exchange over a Mediterranean annual grassland in California, Agr. Forest Meteorol., 1232, 79-96, 2004.

Zhao, L., Li, Y. N., Xu, S. X., Zhou, H. K., Gu, S., Yu, G. R., and Zhao, X. Q.: Diurnal, seaonal and annual variation in net ecosystem $\mathrm{CO}_{2}$ exchange of an alpine shrubland on Qinghai-Tibetan plateau, Glob. Change Biol., 12, 1940-1953, 2006.

Zhao, L., Li, Y. N., Zhao, X. Q., Xu, S. X., Tang, Y. H., Yu, G. R., Gu, S., Du, M. Y., and Wang, Q. X.: Comparative study of the net exchange of $\mathrm{CO} 2$ in 3 types of vegetation ecosystems on the Qinghai-Tibetan Plateau, Chin. Sci. Bull., 50, 1767-1774, 2005.

Zhao, X. Q. and Zhou, X. M. Ecological basis of alpine meadow ecosystem management in Tibet: Haibei Alpine Meadow Ecosystem Research Station, Ambio, 8, 642-647, 1999. 